\title{
IMPROVING LIVES TOGETHER \\ IN BANGLADESH
}

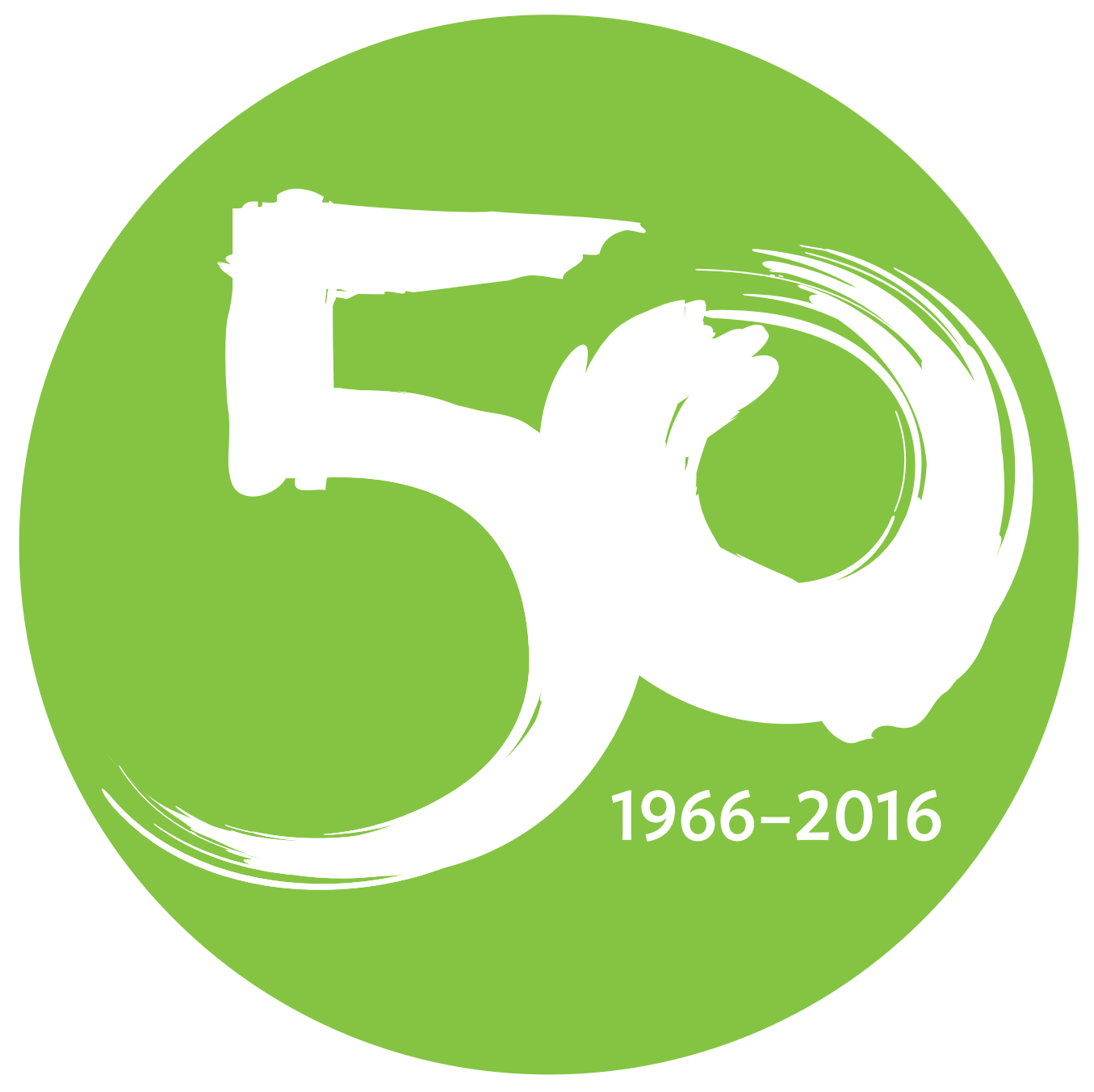

50 YEARS OF THE ASIAN DEVELOPMENT BANK 



\section{IMPROVING LIVES TOGETHER IN BANGLADESH}

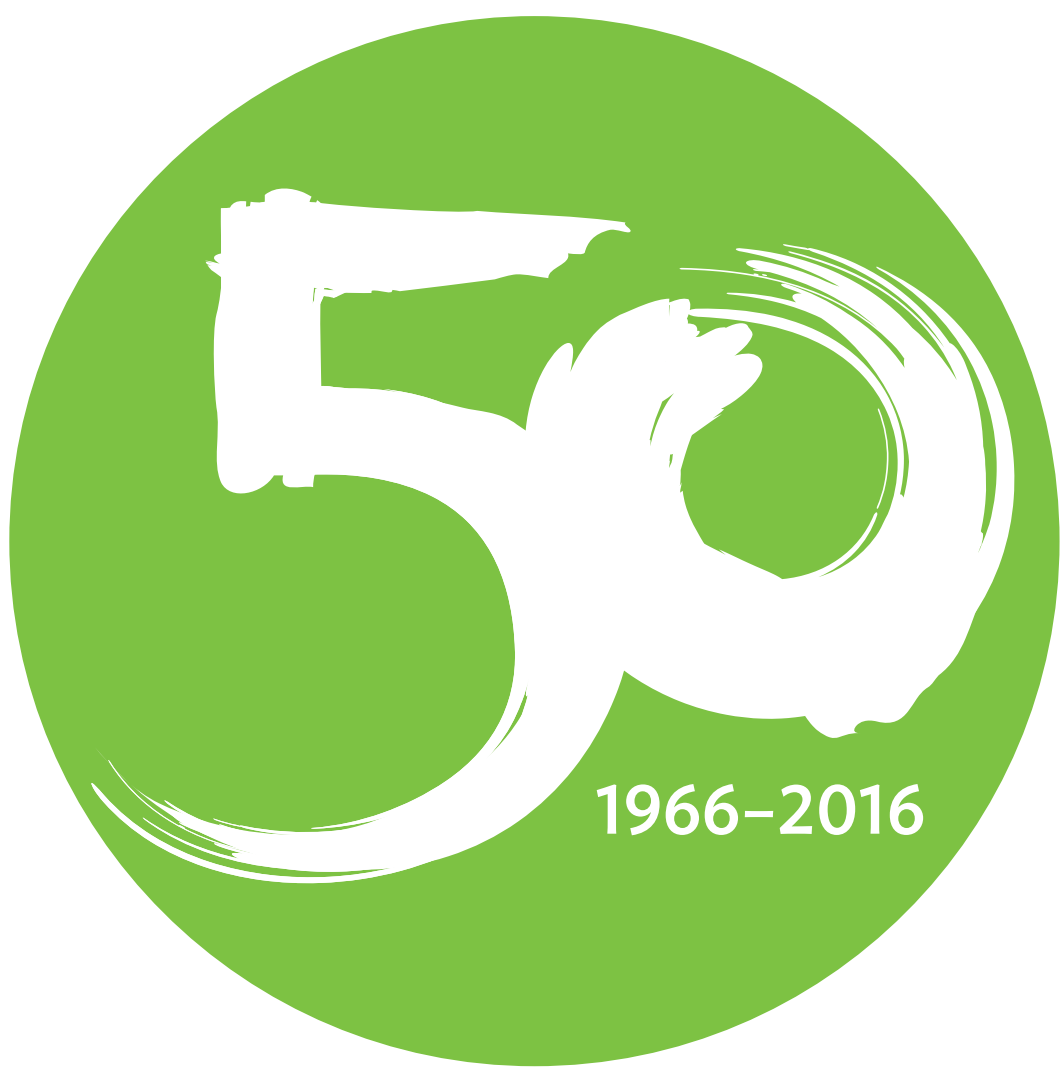

50 YEARS OF THE ASIAN DEVELOPMENT BANK

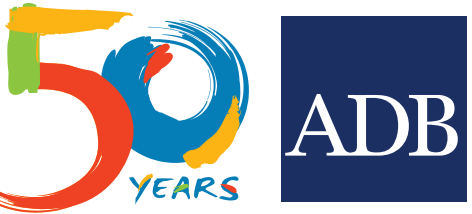


(C) 2017 Asian Development Bank

6 ADB Avenue, Mandaluyong City, 1550 Metro Manila, Philippines

Tel +632632 4444; Fax +6326362444

www.adb.org

Some rights reserved. Published in 2017

Publication Stock No. ARM178832-2

DOI: http://dx.doi.org/10.22617/ARM178832-2

The views expressed in this publication are those of the authors and do not necessarily reflect the views and policies of the Asian Development Bank (ADB) or its Board of Governors or the governments they represent. By making any designation of or reference to a particular territory or geographic area, or by using the term "country" in this document, ADB does not intend to make any judgments as to the legal or other status of any territory or area.

This work is available under the Creative Commons Attribution 3.0 IGO license (CC BY 3.0 IGO) https://creativecommons.org/licenses/by/3.0/igo/. By using the content of this publication, you agree to be bound by the terms of this license. For attribution, translations, adaptations, and permissions, please read the provisions and terms of use at https:/www.adb.org/termsuse\#openaccess

This CC license does not apply to non-ADB copyright materials in this publication. Please contact pubsmarketing@adb.org if you have questions or comments with respect to content or permission to use. Corrigenda to ADB publications may be found at http://www.adb.org/publications/corrigenda

Notes:

In this publication, "\$" refers to US dollars.

Photo: Abir Abdullah, M R Hasan, and Shafiqul Alam Kiron

Design \& Print: Color Horizon, Dhaka 


\section{CONTENTS}

Bangladesh: A Progressive Journey $\quad 5$

$\begin{array}{ll}\text { An Evolving Partnership for Development } & 7\end{array}$

Achieving Results Together $\quad 11$

$\begin{array}{ll}\text { Milestones in Development Cooperation } & 15\end{array}$

$\begin{array}{ll}\text { A Bridge to Prosperity } & 15\end{array}$

$\begin{array}{ll}\text { Doing Better in School } & 17\end{array}$

$\begin{array}{ll}\text { Livable Cities and Towns } & 21\end{array}$

$\begin{array}{ll}\text { Harvesting Potential } & 24\end{array}$

$\begin{array}{ll}\text { Power to the People } & 27\end{array}$

Making Results Visible $\quad 31$

$\begin{array}{ll}\text { Looking Ahead } & 35\end{array}$

This publication was prepared as a collaborative effort involving many staff in the Asian Development Bank. Hun Kim, Director General, South Asia Department; and Kazuhiko Higuchi, Country Director, Bangladesh Resident Mission provided overall guidance and direction. Gobinda Bar, Team Leader, External Relations, prepared and produced the publication, with support from Peter Fredenburg (consultant). 



\section{BANGLADESH: A PROGRESSIVE JOURNEY}

Occupying a vast river delta, Bangladesh is a land of opportunity. Since its independence in 1971, the country has done much to leverage its strengths toward ensuring a secure and prosperous future, gaining lower-middle-income status in July 2015.

Today, the country strives to improve its infrastructure and business climate and the quality of its workforce. Tackling the impacts of climate change is a major development priority.

Most significantly, Bangladesh achieved the Millennium Development Goal of halving poverty as the rate fell from $57 \%$ in 1990 to $49 \%$ in $2000,32 \%$ in 2010, and less than $24 \%$ in 2016 (years are fiscal years ending on 30 June of that year). Population growth fell from nearly $3 \%$ annually in 1979 to $1 \%$ in 2016. Food production more than doubled, improving food availability per capita.

Bangladesh has significant potentials for reaping the rewards of demographic dividend, if people of working age can be converted to human capital and utilized in a productive manner

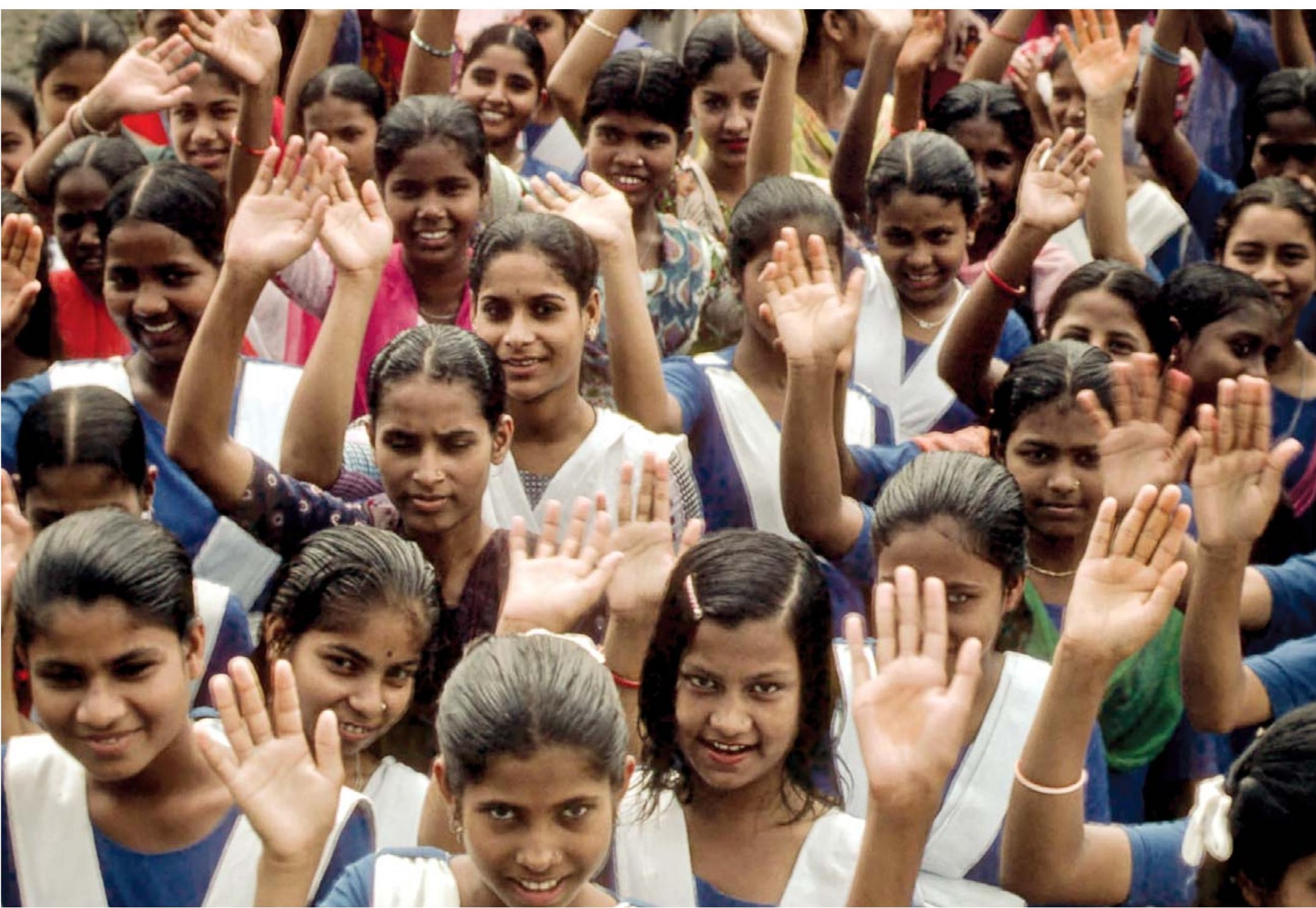


Bangladesh has eliminated gender disparity in primary and secondary education and has nearly achieved universal primary education.

Bangladesh has made steady progress in recent years, with notable improvement in infrastructure
Life expectancy extended from 56 years in 1990 to nearly 70 years in 2015, with the number of infants who died in their first year plunging by more than two-thirds and maternal mortality falling almost as steeply. Adult literacy climbed from $37 \%$ in 1990 to $65 \%$ in 2015 . Bangladesh has eliminated gender disparity in primary and secondary education and has nearly achieved universal primary education, recording 2015 net enrolment rates at $99 \%$ for girls and $97 \%$ for boys.

Gross domestic product (GDP) expansion has averaged $4.7 \%$ over the past 45 years, improving from an average of $3.5 \%$ in the 1980 s to $4.8 \%$ in the 1990 s, $5.4 \%$ from 2001 to 2005 , and $6.3 \%$ from 2006 to 2015. GDP growth reached a high of $7.1 \%$ in fiscal 2016. It is projected at $6.9 \%$ in 2017 , despite the continuing global slowdown since the global financial crisis of 2008-2009.

Official development assistance accounts for only half of the GDP as in the mid-1990s, when it provided $4 \%$, but still funds nearly one-third of development program spending. Growth has been inclusive with jobs created for low-skilled workers and women, in particular producing ready-made garments for export. Also contributing to poverty reduction are expanded microcredit; improved access to health and social services; and higher remittances.

Further, prudent macroeconomic management in recent years has helped slow inflation, build up foreign exchange reserves, hold the currency exchange rate steady, restrain fiscal deficits, and shrink external debt as a percentage of GDP. 


\section{AN EVOLVING PARTNERSHIP FOR DEVELOPMENT}

Since Bangladesh became a member of the Asian Development Bank (ADB) in 1973, the partnership has extended to almost all areas of the economy. By the end of 2016, ADB had provided $\$ 18.3$ billion in 272 loans, $\$ 249.37$ million in 450 technical assistance projects, $\$ 804.6$ million in 42 grants, $\$ 422.3$ million in private investment, and $\$ 2.2$ billion in trade financing.

By sector, transport received $24 \%$ by value of all grants, technical assistance, and sovereign and nonsovereign loans approved in 2016. Energy followed at 23\%; agriculture, natural resources, and rural development at $12 \%$; and education at $10 \%$. Significant amounts were allocated to (in descending order) finance; water and urban infrastructure and services; public sector management; multisector projects; industry and trade; health; and information and communication technology.

The agreement establishing ADB's first field office, the Bangladesh Resident Office (now known as Bangladesh Resident Mission), was signed on 16 July 1982. Seated from left: Executive Director G. Ramachandran; Alternate Executive Director for Bangladesh, Kafiluddin Mahmood; ADB President Masao Fujioka; ADB Vice-President Ashok T. Bambawale; ADB VicePresident S. Stanley Katz. Standing from left: ADB Senior Counsel, Office of the General Counsel, Desha-Priya Cuthbert Amerasinghe; and first Country Director of BRM Song Chil Lee.

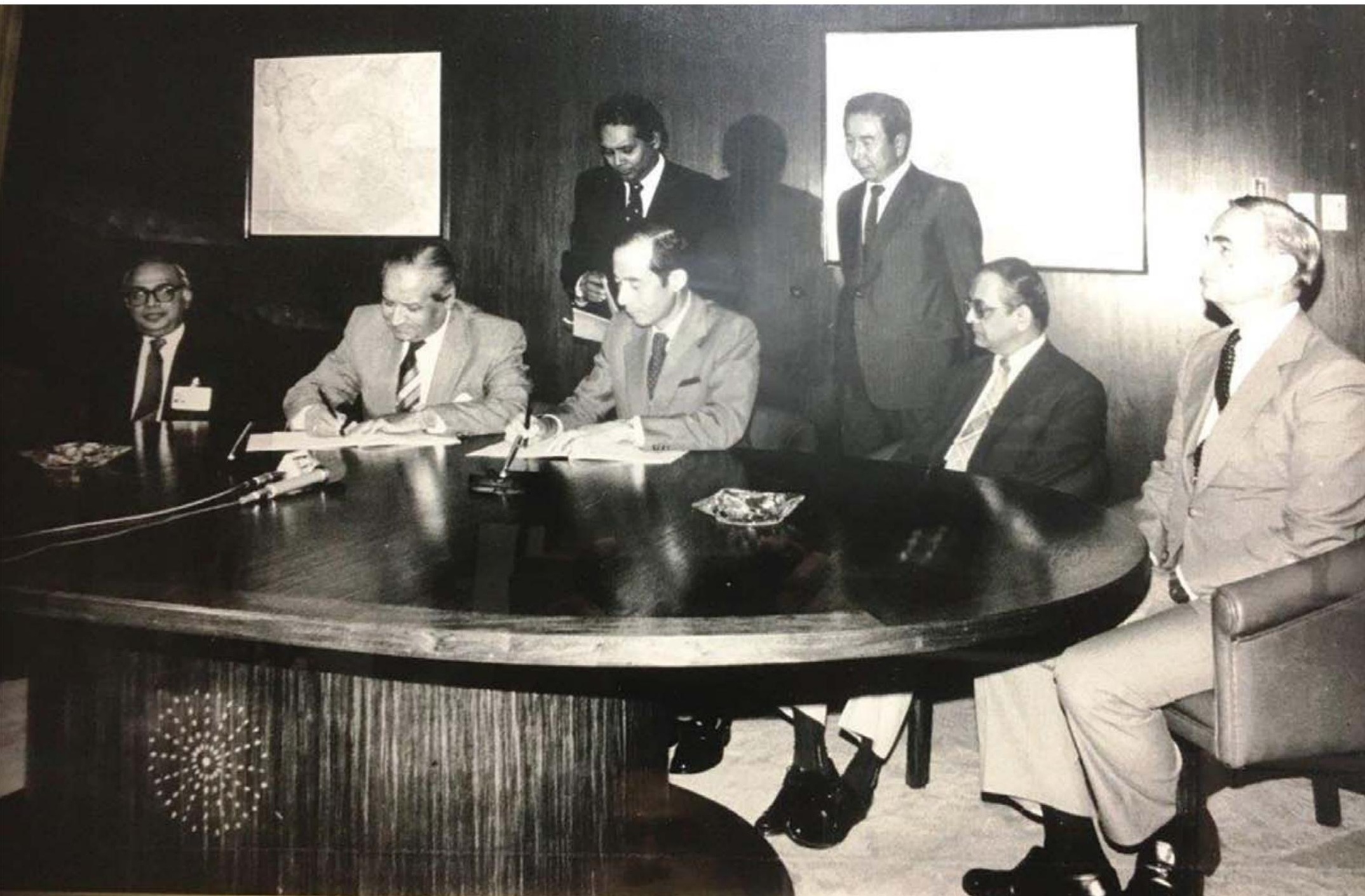




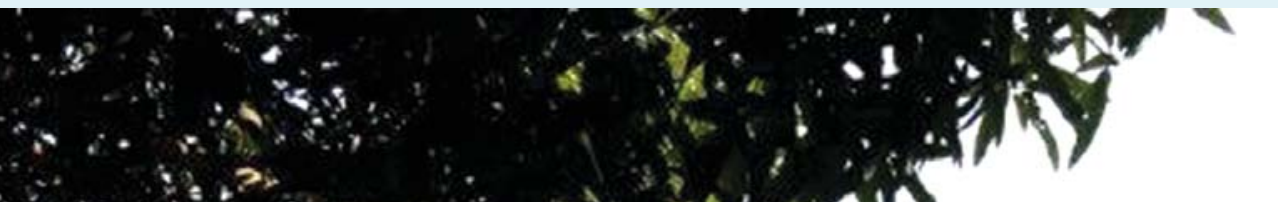

$0, m^{n}$

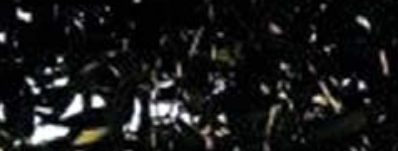

ox $=0$

$d=2,0$

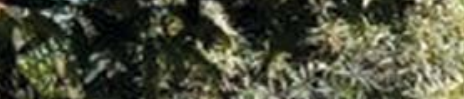

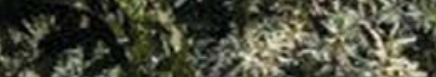

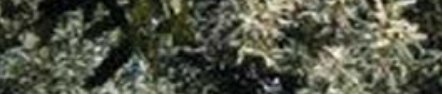

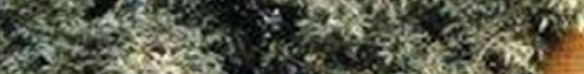

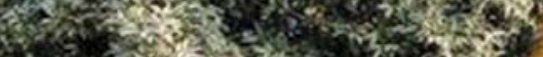

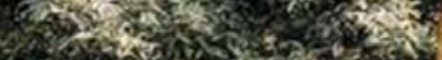

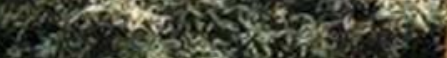

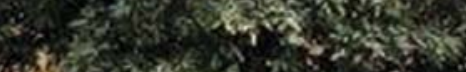

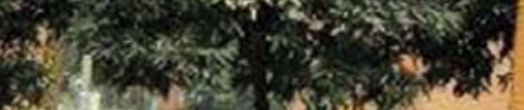
the

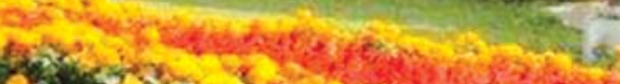

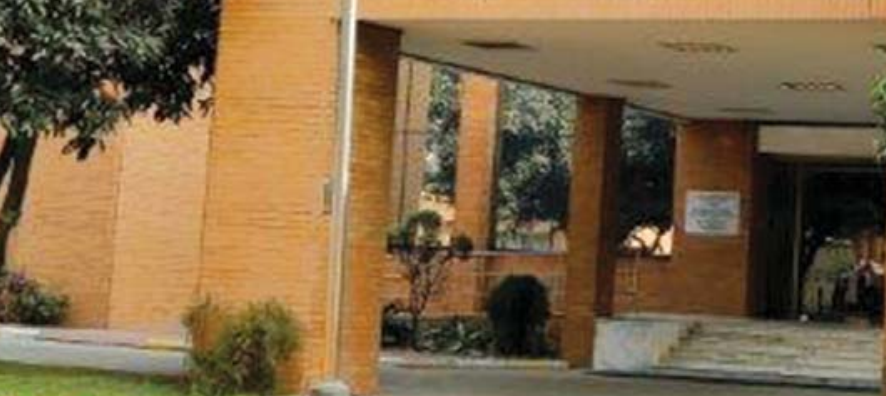

$\mathrm{ADB}$

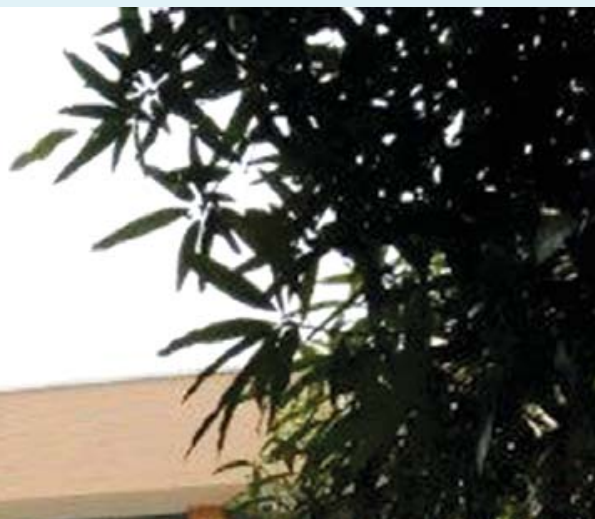

tes,

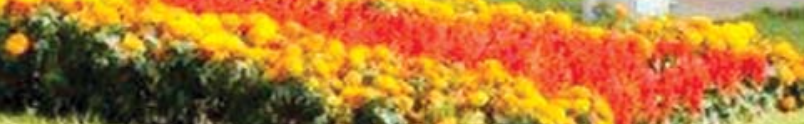

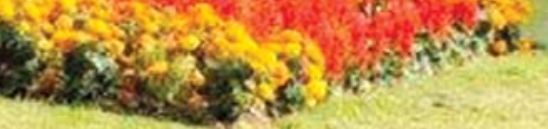

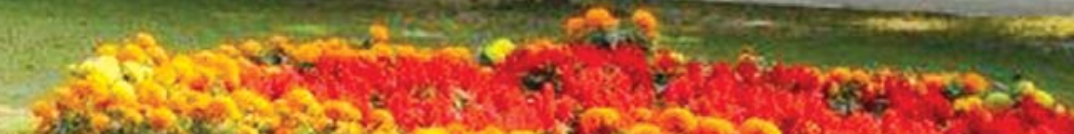
(civive 46. $4 \div \div$

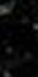

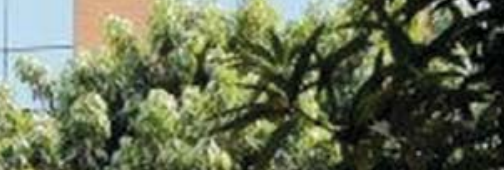 5 .} 23is? 3.

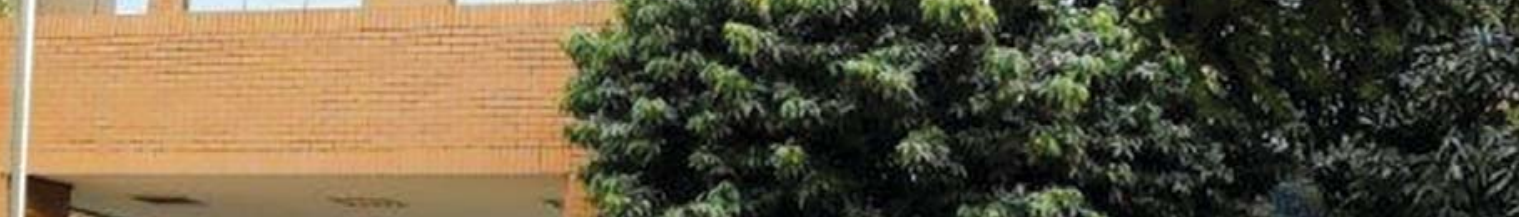
3.

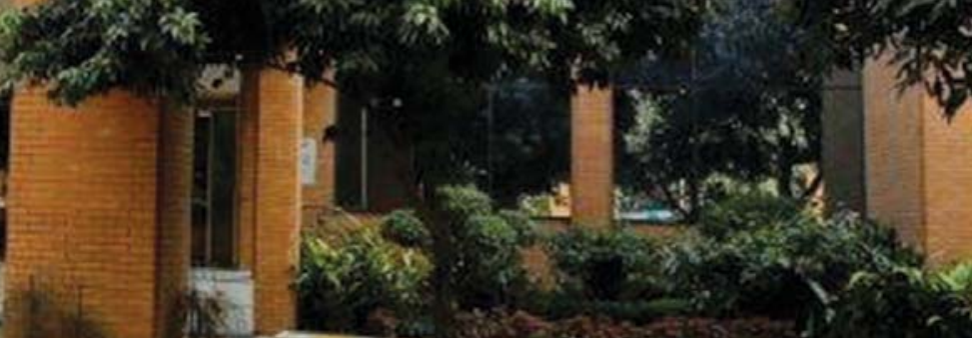

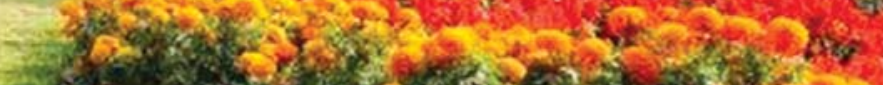

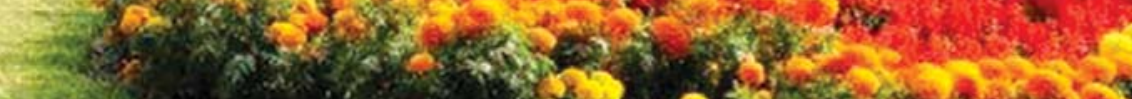

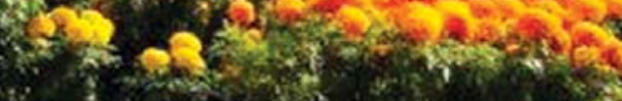

sins

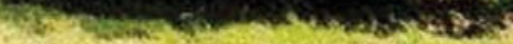


Soon after the partnership began, the government and ADB began to focus on reconstructing infrastructure damaged during the war of independence, and on boosting the rural economy to feed a new but impoverished nation of 70 million. Two loans were quickly approved to improve fish marketing facilities and access to credit for firms producing jute, cotton textiles, and other manufactured goods. Two more loans, for electric power and port development at Chittagong, were approved in 1973.

In the first decade, agriculture and natural resources received $37 \%$ of ADB assistance. This expanded farmers' access to credit and inputs such as seed and fertilizer and strengthened irrigation; drainage and flood protection; natural resource management; fisheries and livestock; and market and rural development. A concessional loan in 1975, for example, established the Ashuganj fertilizer plant using natural gas.

In 1974, ADB extended its first loan for a rail project, which repaired and improved the DhakaChittagong line and other parts of the national rail system. Support for infrastructure eased the movement of basic commodities such as food.

To speed the processing of high-priority loans, $A D B$ designed a quick-disbursing modality for programs in 1978. In the same year, ADB provided its first program loan for the Low-Lift Pump Maintenance Program to support the operations of the Bangladesh Agricultural Development Corporation.

In the 1980s, the focus turned to policy and institutional reform across sectors in keeping with the government's shift in emphasis toward a leading role for the private sector. Transport and electric
ADB supports railways development in Bangladesh

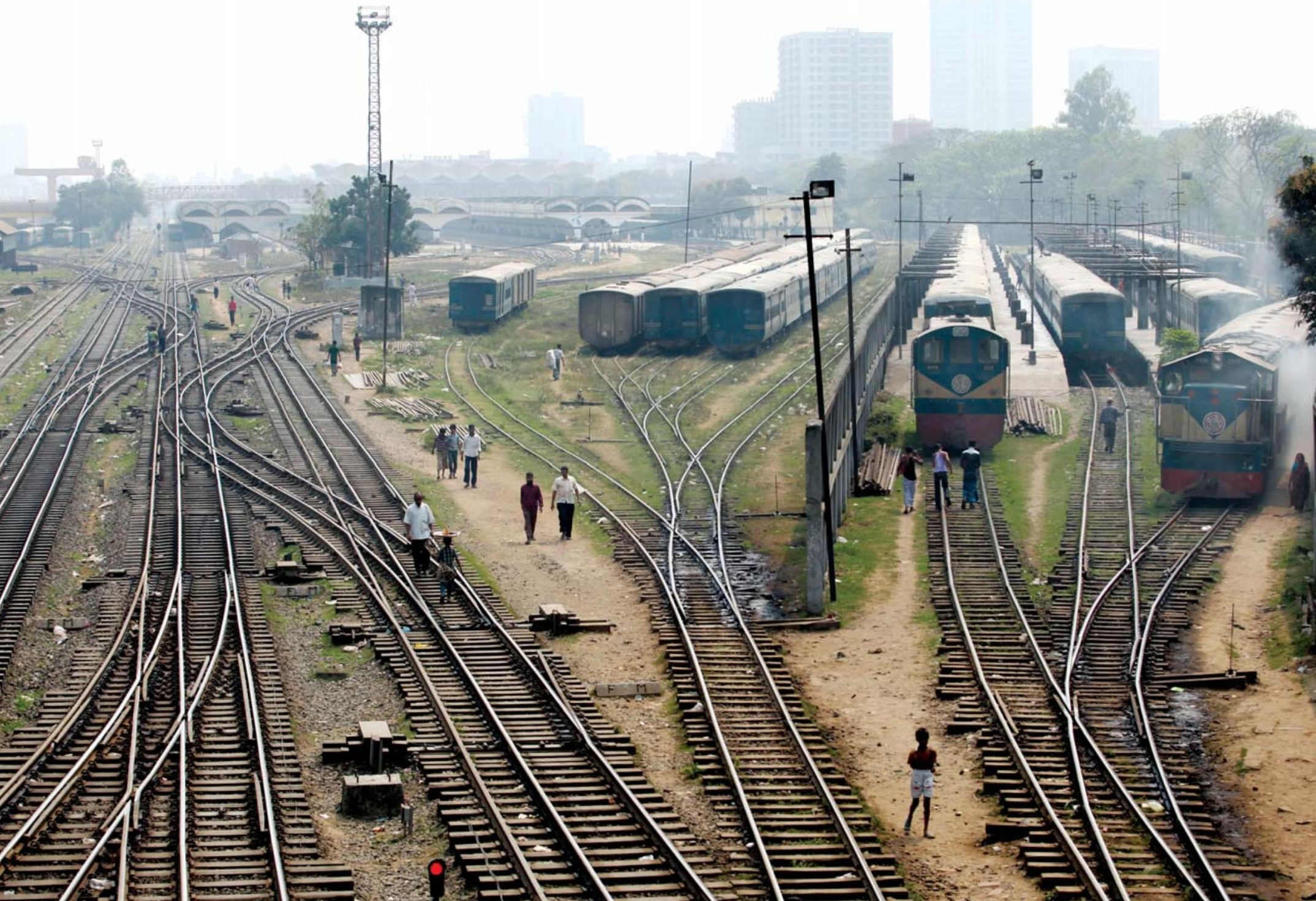


power became high priorities, together receiving $55 \%$ of allocations. ADB also added gas development to the portfolio of large energy and transport projects. Support for education, health, urban development, and other social infrastructure development started to pick up to serve the overriding objective of poverty reduction.

Since 2000, ADB has expanded support for smaller-scale infrastructure such as water supply and sanitation; small and medium-sized enterprise development; primary education and health; disaster risk management; and improved governance through capacity enhancement and policy advice.

The Bangladesh Resident Mission has the distinction of being the first ADB field office, opening in 1982 and moving into its own building in 2004. Having provided proof of concept for 31 satellite offices, the ADB office in Dhaka remains one of the largest, with some 60 staff.

A leading partner in energy sector, ADB has

helped Bangladesh develop major gas fields (Titas, Habiganj, and Bakhrabad), gas transmission systems, and most distribution networks across the country since 1975

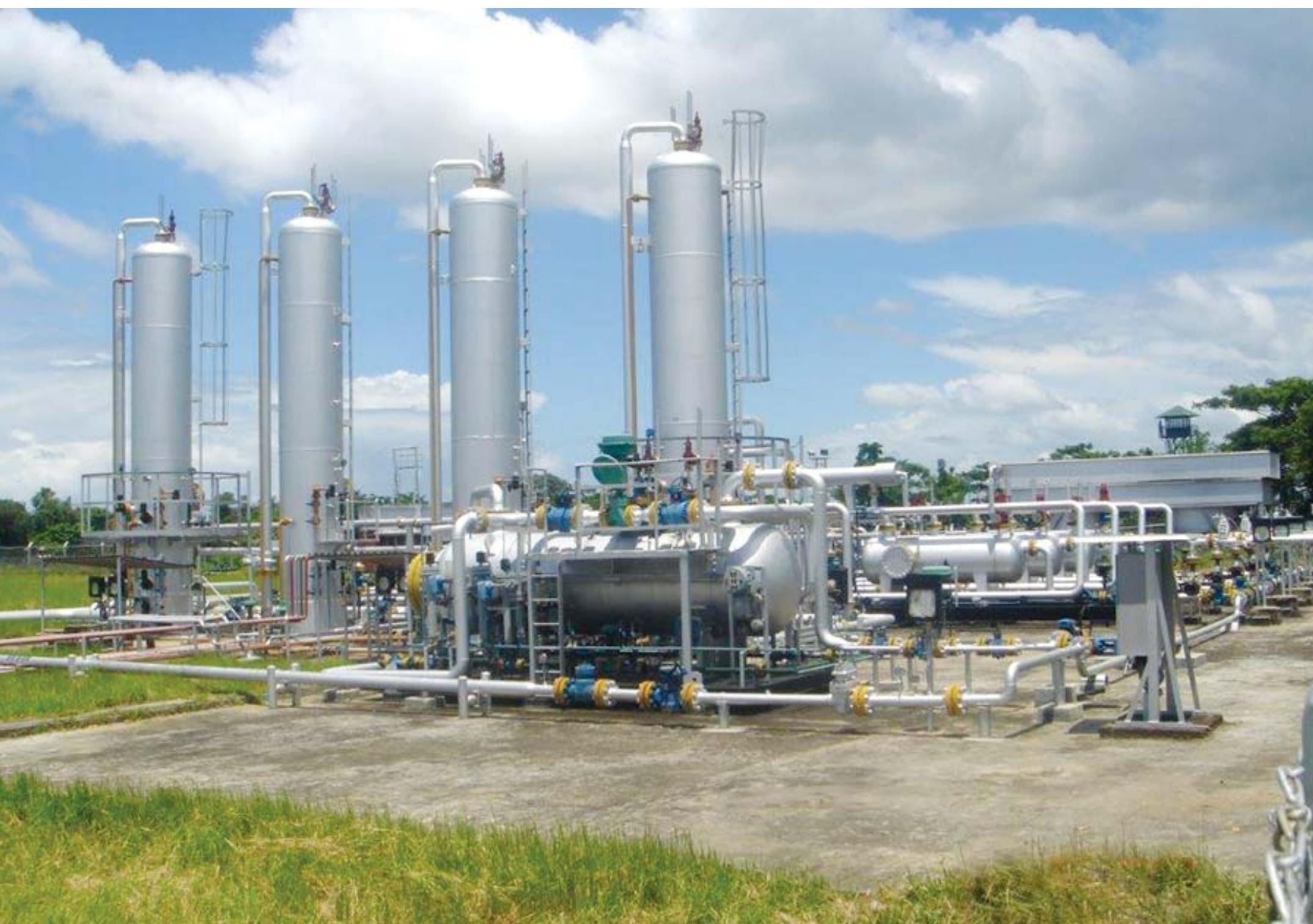




\section{ACHIEVING RESULTS TOGETHER}

ADB is a leading multilateral development partner of Bangladesh in transport, energy, and education. In 2016, it approved 10 loans totaling $\$ 1.11$ billion and technical assistance worth $\$ 7.85$ million. ADB also mobilized $\$ 841.7$ million in cofinancing.

As of December 2016, the ADB portfolio in Bangladesh comprised 54 projects amounting to $\$ 7.2$ billion and 28 technical assistance projects worth $\$ 27$ million.

In energy development, the \$120 million Second Bangladesh-India Electric Grid Interconnection Project will help increase imports of much-needed electricity to users in Bangladesh, and the \$205 million third tranche of the Power System Expansion and Efficiency Improvement Investment

ADB helped introduce modern classroom teaching methodologies

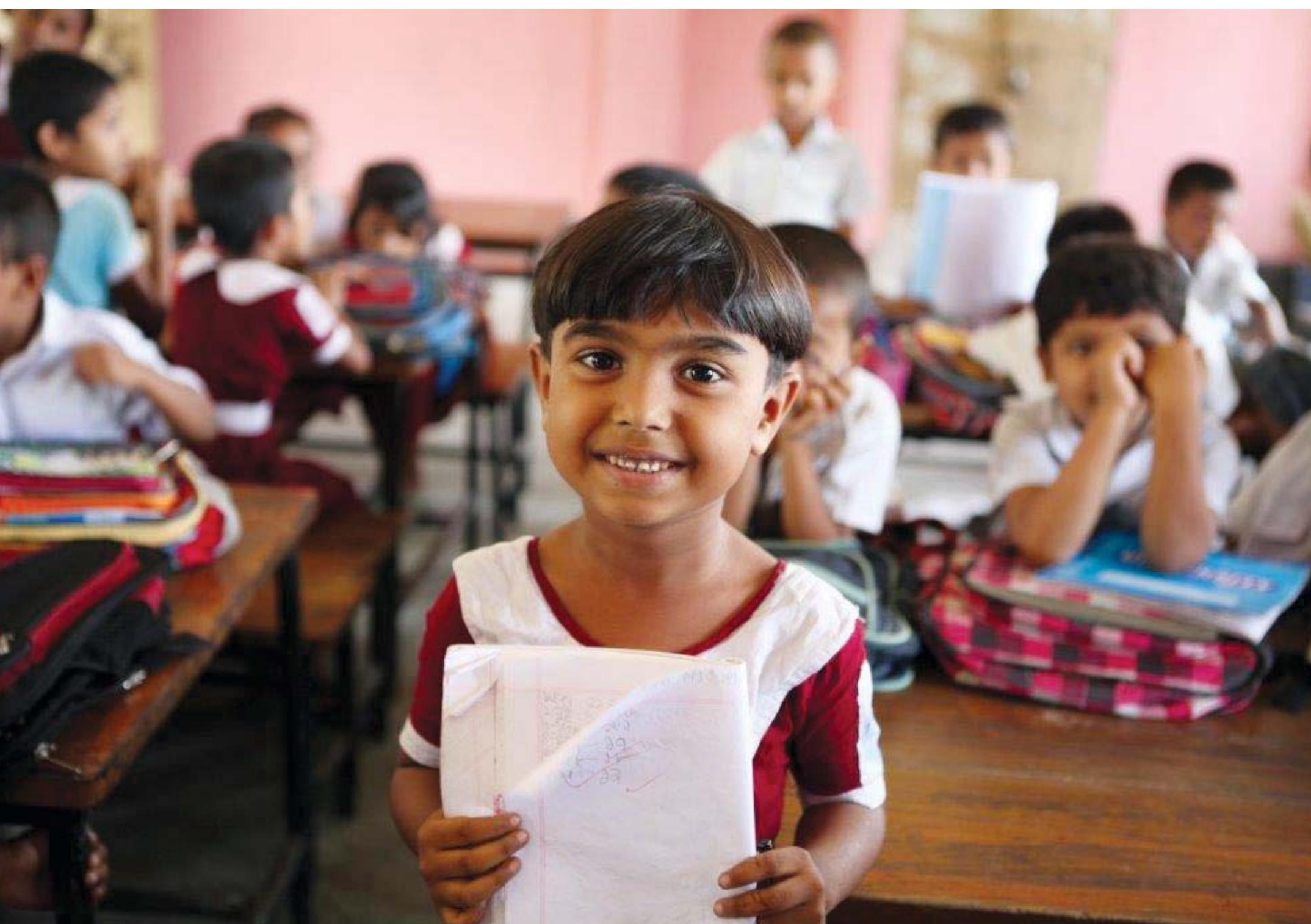




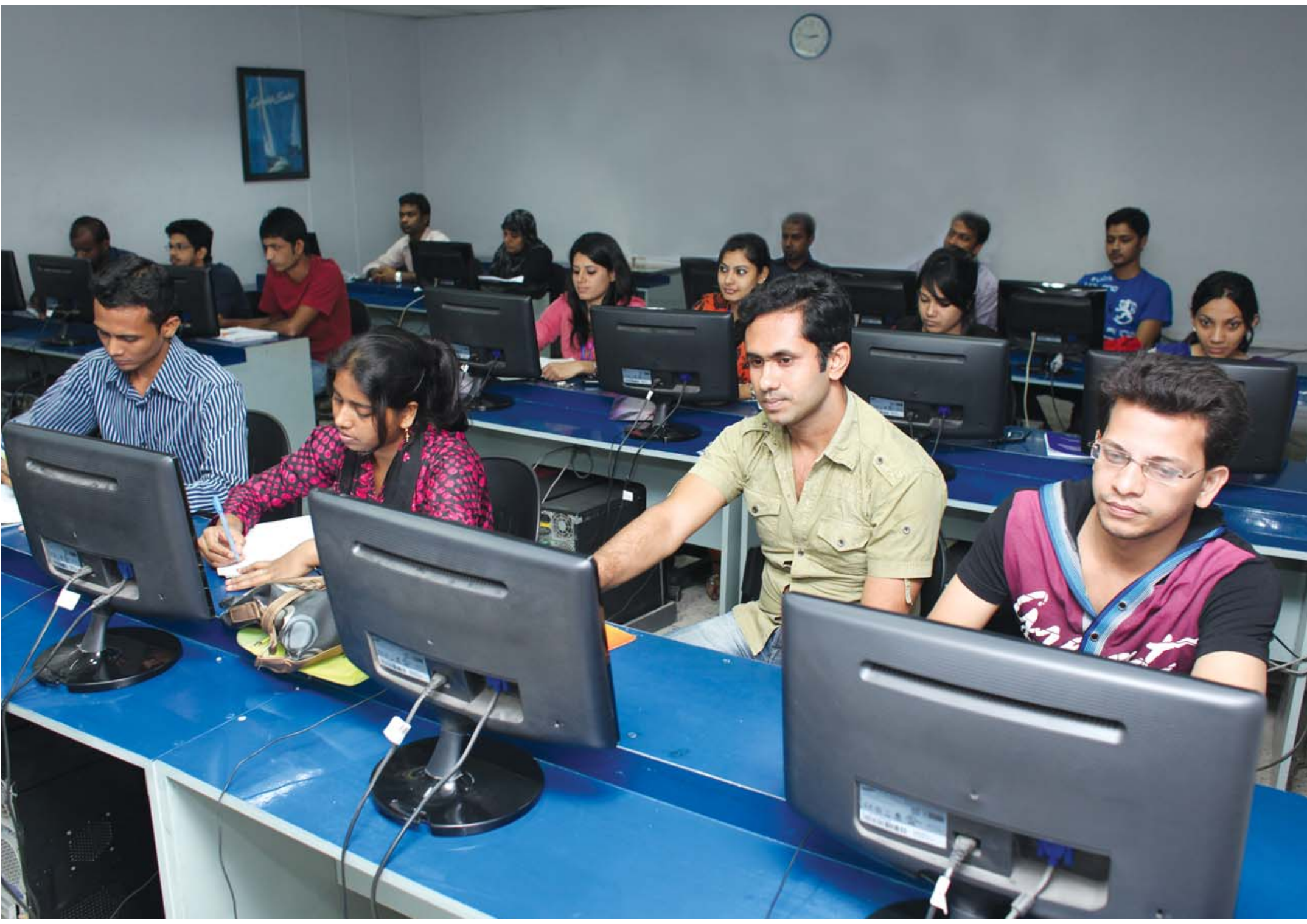

Skills and human development form part of ADB's key focus in Bangladesh
Program will boost power supply and coverage to users. Ongoing projects support the construction of new electricity generating capacity, transmission and distribution lines, and substations.

In transport, the $\$ 200$ million Railway Rolling Stock Project will improve rail services in Bangladesh, further promoting clean and affordable public transport, and \$30 million in additional financing for the Subregional Transport Project Preparatory Facility will prepare transport projects to improve regional connectivity and facilitate regional trade. Ongoing railway projects are implementing system reform, double-tracking lines, and improving signaling systems. A \$1.5 billion project approved in 2016 will extend the rail corridor from Chittagong to Cox's Bazar, near the border with Myanmar. Ongoing road projects are upgrading roads and land ports, as well as constructing bus rapid transit lanes.

In education, the $\$ 185$ million second tranche of the Secondary Education Sector Investment Program will help enhance education quality and develop skills, thus improving employability and contributing to inclusive growth. So will the $\$ 440$ million Third Primary Education Development Project, which follows on one of the five signature projects explored in the next section of this report 
(Doing Better in School, page 17) An ongoing 7-year program aims to orient skills development to labor market needs.

The ongoing City Region Development Project rehabilitated 28 kilometers $(\mathrm{km})$ of canals, $12 \mathrm{~km}$ of secondary and tertiary drainage systems, and flood-control structures to ease waterlogging problems in Khulna, benefiting over half a million people. The Khulna Water Supply Project is introducing surface water sources to reduce ground water extraction and salinity intrusion in this coastal city affected by climate change.

Additional financing of \$45 million for the Southwest Area Integrated Water Resources Planning and Management Project will strengthen resilience under climate change by improving water management and flood control, as well as community participation in these imperatives. Toward climate change mitigation, an ongoing project to modernize brick-making is replacing badly polluting kilns with high-capacity kilns that are more energy efficient. A project to extend electric power to 450,000 households will reduce annual carbon emissions by almost 2.5 million tons starting in 2018 .

The $\$ 250$ million Third Capital Market Development Program will support capital market reform, strengthen institutions, and contribute to the development of capital and bond markets.

With a focus on rural development, other ongoing projects promote diversification toward crops with commercial potential and the mainstreaming of gender issues. These projects are also improving water management and rural road access.

\section{Secondary}

Education Sector

Investment

Program will

help enhance

education

quality and

develop skills,

thus improving

employability

and contributing

to inclusive

growth.

Empowering women through job creation has been mainstreamed in all ADB-assisted projects in Bangladesh

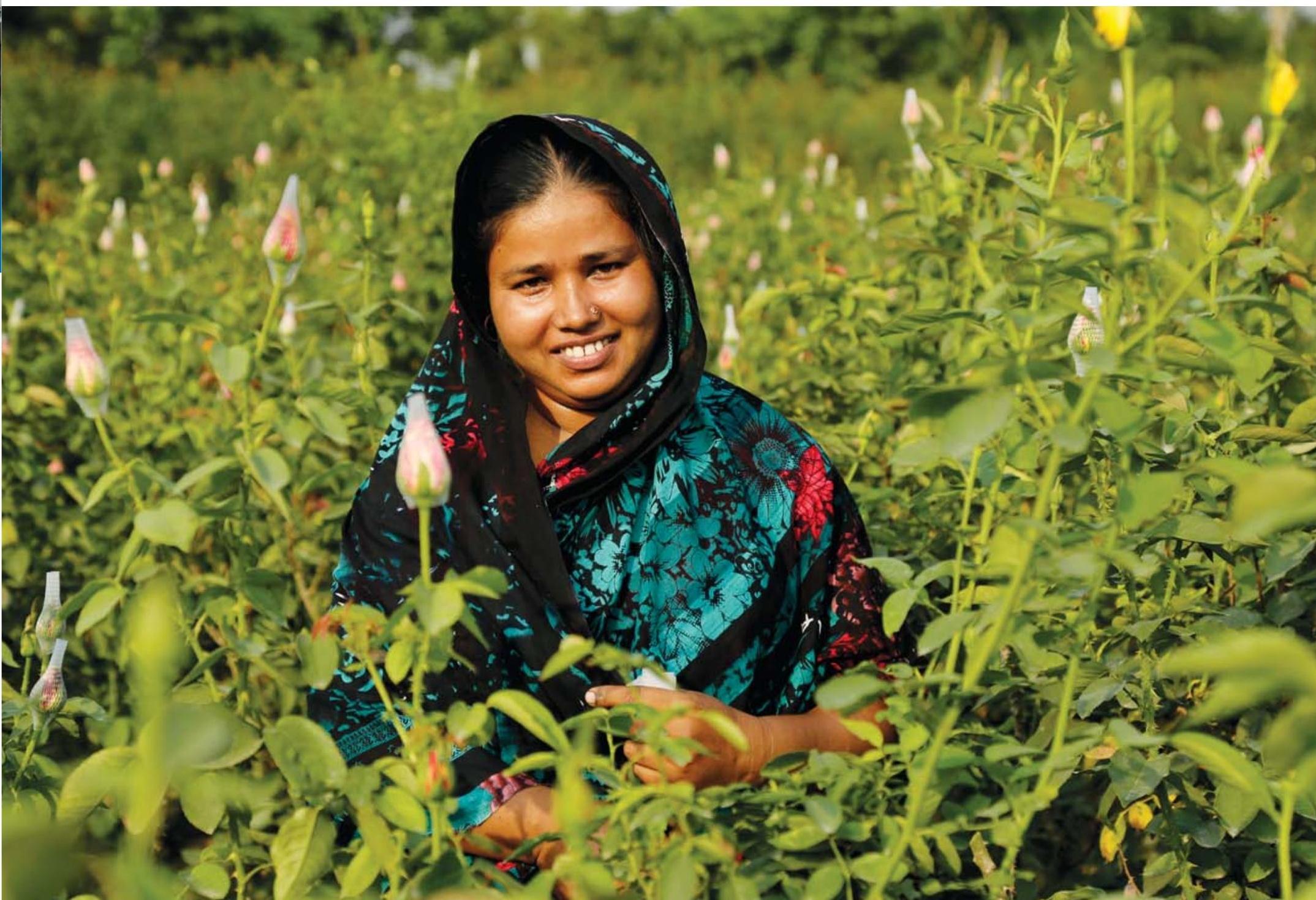



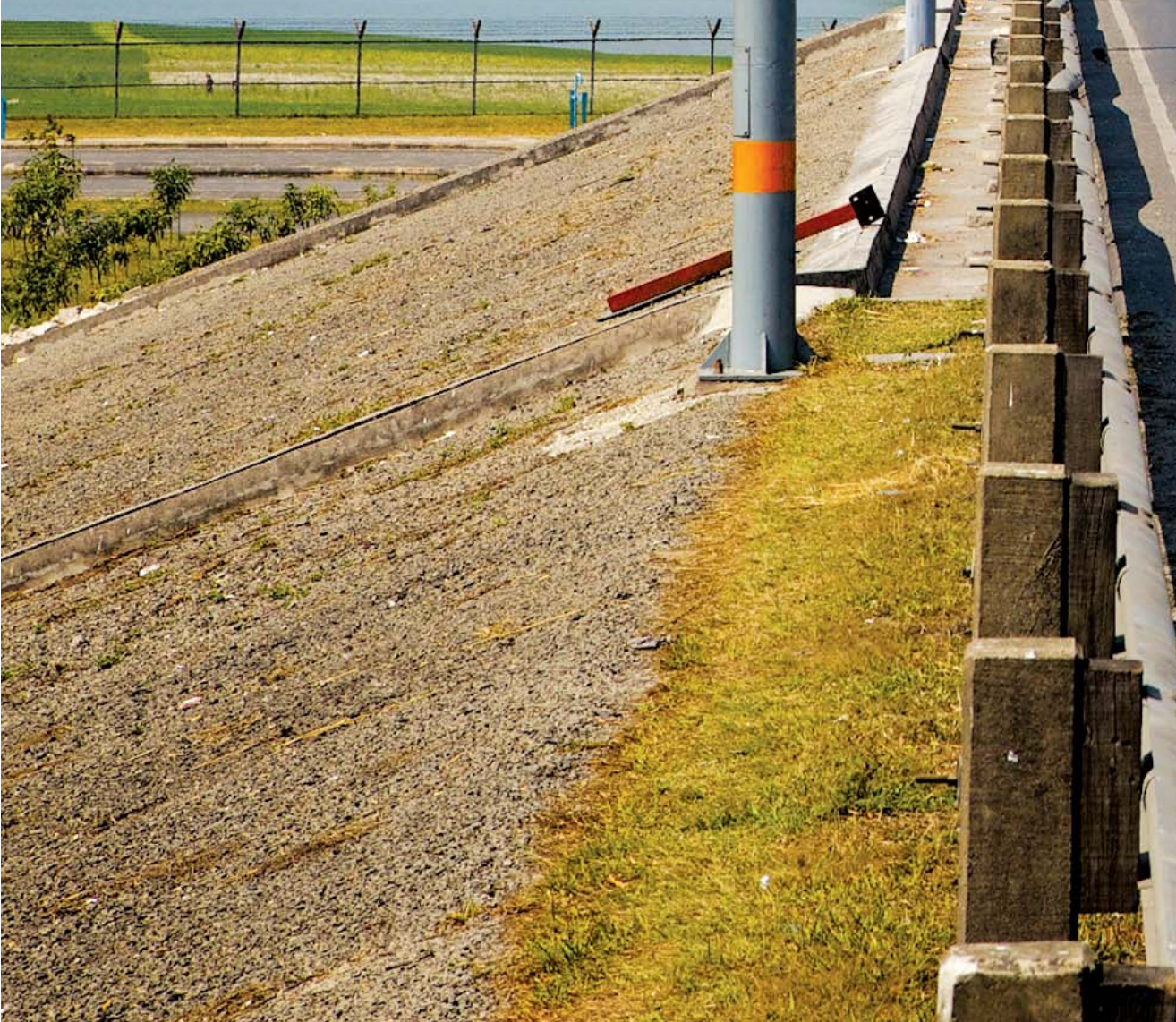


\section{MILESTONES IN DEVELOPMENT COOPERATION}

Among the many milestones in the Bangladesh-ADB partnership, the following five projects exemplify sustained development results. They supported advances in transport, energy, and education; addressed food security; improved rural livelihoods; and helped tackle the issues arising from urban growth in one of the world's most crowded countries.

\section{A Bridge to Prosperity} When the Bangabandhu Multipurpose Bridge opened in 1998, previously isolated northwestern
Bangladesh acquired new opportunities to participate in national development.

The Jamuna River, one of the world's largest, is a great artery for transport and trade. The advent of modern land transport, however, turns rivers such as the Jamuna into obstacles that impede rapid and reliable transport by road and rail. The Jamuna thus became a barrier to development in northwestern Bangladesh, physically separating its 30 million inhabitants from the more developed eastern part of the country.

Although the western half of Bangladesh boasts fertile land for agriculture and higher crop yields than the rest of the country, it has languished as the poorer half, dependent on agriculture as the mainstay of its economy. To market agricultural products, farmers and shippers in the northwest needed quick access to the more developed eastern part, including both the capital at Dhaka and the main seaport at Chittagong.

The Jamuna River could be crossed only by manually operated boats for passengers and goods, and by motor ferries for cars, trucks, and train passengers. The wet monsoon and resulting to high river flows from May to October impeded crossings. Frequent and long delays at ferry crossings drove up transport costs for passengers and freight.

In 1994, the government engaged financial assistance from ADB, the World Bank, and Japan to build what would become the longest bridge in South Asia and the eleventh longest in the world, 4 years later. The project was a large undertaking that required training the banks of the Jamuna River on both sides. With a price tag approaching $\$ 1$ billion, the Bangabandhu Multipurpose Bridge was Bangladesh's most expensive transport project and one of its most technically challenging.

Truck driver Abdul Halim could hardly be happier with the result. "Until 1998, transporting fruits and vegetables to markets in Dhaka was a tedious 14-hour or longer journey using ferry services," he explained. "Shippers routinely suffered losses of perishable goods." The situation changed after the Bangabandhu Bridge was built, and highways and other access roads were rehabilitated or constructed.

The bridge is estimated to have allowed 1 million Bangladeshis to climb out of poverty. 
"Now I can drive to Dhaka in just 5 hours, in any weather and at any time of the day or night," Halim added. "In addition, with the shortened route, the bridge and the improved roads have reduced fuel consumption and wear and tear on my truck."

Comparing 1997

with 2012,

passenger traffic

to and from the

northwest

increased by

$18 \%$, the volume

of interregional

trade by $5 \%$, the

movement of

trucks by $89 \%$, and the

movement of

buses by $130 \%$.

Bangabandhu Multipurpose Bridge
As the Bangabandhu Bridge slashed the cost of transporting goods and people to and from the northwest, it sharply boosted trade flows and facilitated the migration of labor. Benefits were felt first in the northwest, which immediately enjoyed improved access to markets for its agricultural goods and surplus labor. Comparing 1997 with 2012, passenger traffic to and from the northwest increased by $18 \%$, the volume of interregional trade by $5 \%$, the movement of trucks by $89 \%$, and the movement of buses by $130 \%$. Improved access to higher-income markets in the capital meant higher prices for agricultural produce and substantially improved incomes for farmers in the northwest (Harvesting Potential, page 24).

Measuring $4.8 \mathrm{~km}$ in length and 18.5 meters in width, the multipurpose bridge also carries a rail link, electric power and gas lines, and telecommunications connections. Greater availability and lower costs for electricity and natural gas made the northwest more attractive for transport industries and processing plants, in particular for cement.

Studies have measured benefits further afield as the bridge and consequently higher gas production, electricity generation, and trade flows helped lift the national economy. The bridge is estimated to have allowed 1 million Bangladeshis to climb out of poverty.

Further, by linking rail systems on both sides of the Jamuna River, the bridge facilitates opportunities for subregional integration with Bhutan, India, and Nepal. It now forms part of the Asian Highway and the Trans-Asian Railway. When fully developed, these initiatives will provide uninterrupted road and rail links between Southeast Asia and Europe.

The project was completed on schedule, demonstrating the government's commitment and its ability to implement large and complex projects with multiple stakeholders. Traffic across the bridge is higher than anticipated, indicating benefits beyond expectations at project appraisal.

ADB financed complementary follow-on investment projects to expand the road network on the east side of the Jamuna River and connect the rail networks on either side. It provided \$207 million for the bridge itself and an additional $\$ 182$ million in two projects to improve access road and rail links. 


\section{Doing Better in School}

\section{An innovative education program cofinanced by the government and 11 development partners led by $A D B$ revitalized primary schooling from $A$ to $Z$.}

Primary school enrollment in Bangladesh is a high 98\%. Higher retention and academic achievement is the next goal. With $90 \%$ of primary schools operating in two shifts, serving one set of students in the morning and another in the afternoon, teachers and school facilities are stretched to the limit. Under this double-shift system, contact time between teachers and their pupils is $30 \%$ below the international average.

In response, the Second Primary Education Development Program, initiated in 2003 and completed in 2012, recruited 45,000 new teachers, intensively trained another 95,000 teachers, constructed 40,000 new classrooms, and renovated another 10,000 classrooms, allowing participating schools to go to a single shift.

"After we changed the two-shift system to one shift, students' grades began to improve a lot, mainly because we now spend more time on each pupil," said Mirza Johura Akhter, head of the Nayabazar Government Primary School in Syedpur Upazilla of Nilphamari District, where student attendance improved from $75 \%$ to $90 \%$ during project implementation.

A further 320,000 trained staff, including head teachers such as Akhter, received refresher courses. Akhter stressed that frequent in-service training programs improved their basic competencies, particularly in literacy and numeracy.

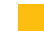

After we changed the two-shift system to one shift, students' grades began to improve a lot, mainly because we now spend more time on each pupil.

Bangladesh is emphasizing on improving overall learning environment to further enhance education quality

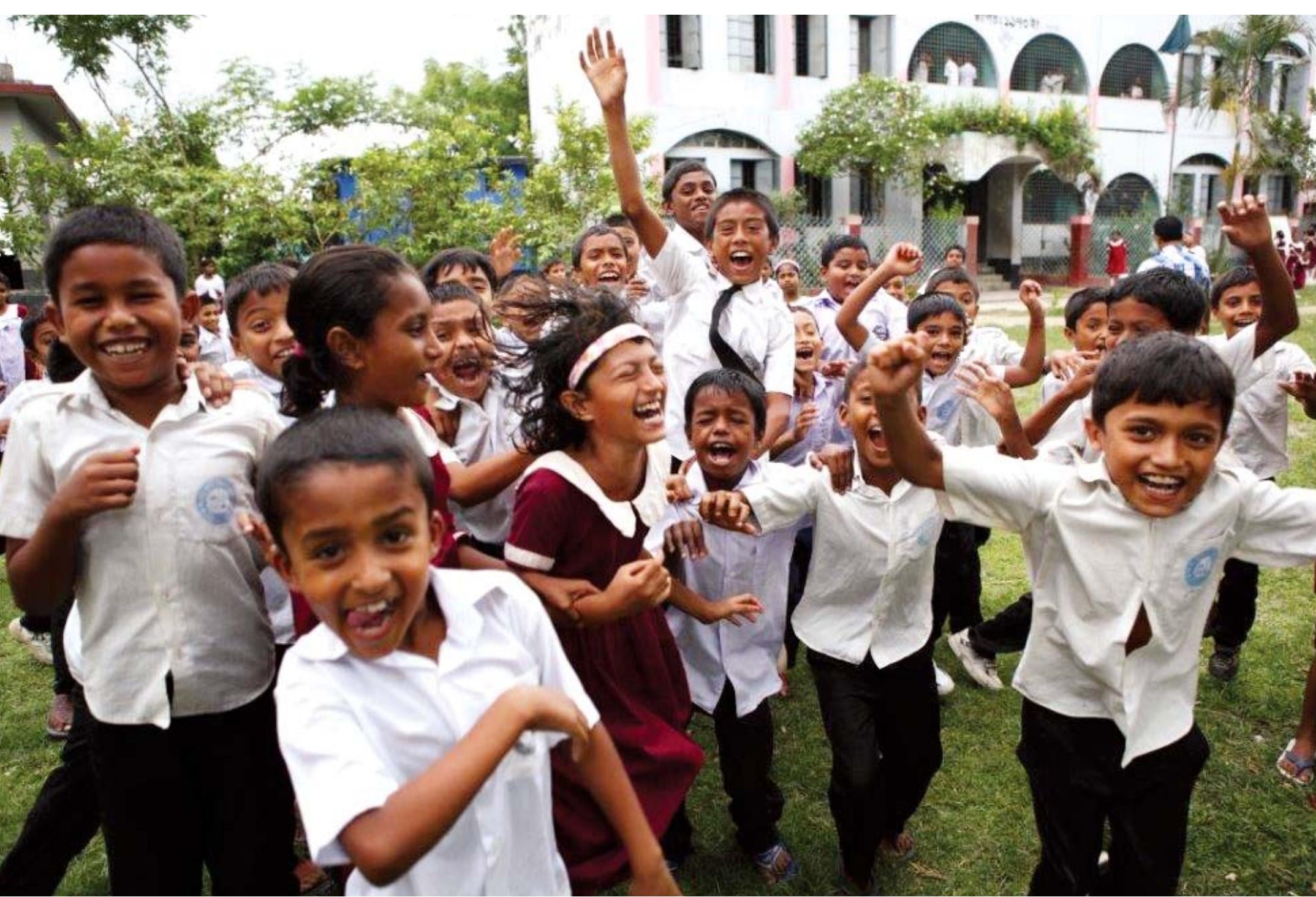




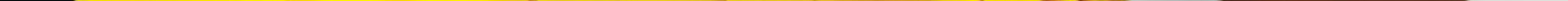


At a participating primary school in northwestern Bangladesh, a poor agricultural region, two new teachers were added, as were two additional classrooms. Toilets and other facilities were upgraded, and new textbooks and teaching materials purchased. A teacher trainer visited several times a week to discuss problems and provide guidance on teaching and the use of materials.

"I want to be a teacher when I grow older," said Devasmita Sarkar, a 10-year-old student. Like many children, she was inspired by her time spent in the improved classroom environment and hoped that school would prepare her for a bright future. Her hope was well founded, as almost all of her schoolmates who took the primary scholarship examination won scholarships.

Having recognized the need to revitalize primary education, the government invested $\$ 1.2$ billion in the $\$ 1.8$ billion program. ADB, the lead partner agency, invested $\$ 109$ million. The remainder was cofinanced by the Australian Agency for International Development, Canadian International Development Agency, Department for International Development of the United Kingdom, European Commission, Japan International Cooperation Agency, the Netherlands, Norwegian Agency for Development Cooperation, Swedish International Development Cooperation Agency, United Nations Children's Fund, and World Bank. The program became a model of harmonized agency procedures for funding, financial management, procurement, reporting, monitoring, auditing, and evaluation.

To address gender inequality in the teaching profession, the program preferentially hired women toward the goal of placing women in $60 \%$ of all primary school teaching positions.

In addition to training teachers, developing educational materials, and expanding classroom numbers and improving their quality, the project addressed policy, institutional, and organizational weaknesses. The adoption of results-based management improved capacity in data collection and analysis and facilitated the production of annual performance reports. Financial management capacity in the Directorate of Primary Education improved. Audits recorded better results with higher awareness of good governance and greater commitment to stringent procurement practices and financial management. Further, the project mainstreamed minimum service standards for primary schools, initiated a comprehensive framework for teacher education and professional development, and adopted a teacher recruitment system that was transparent and based on merit.

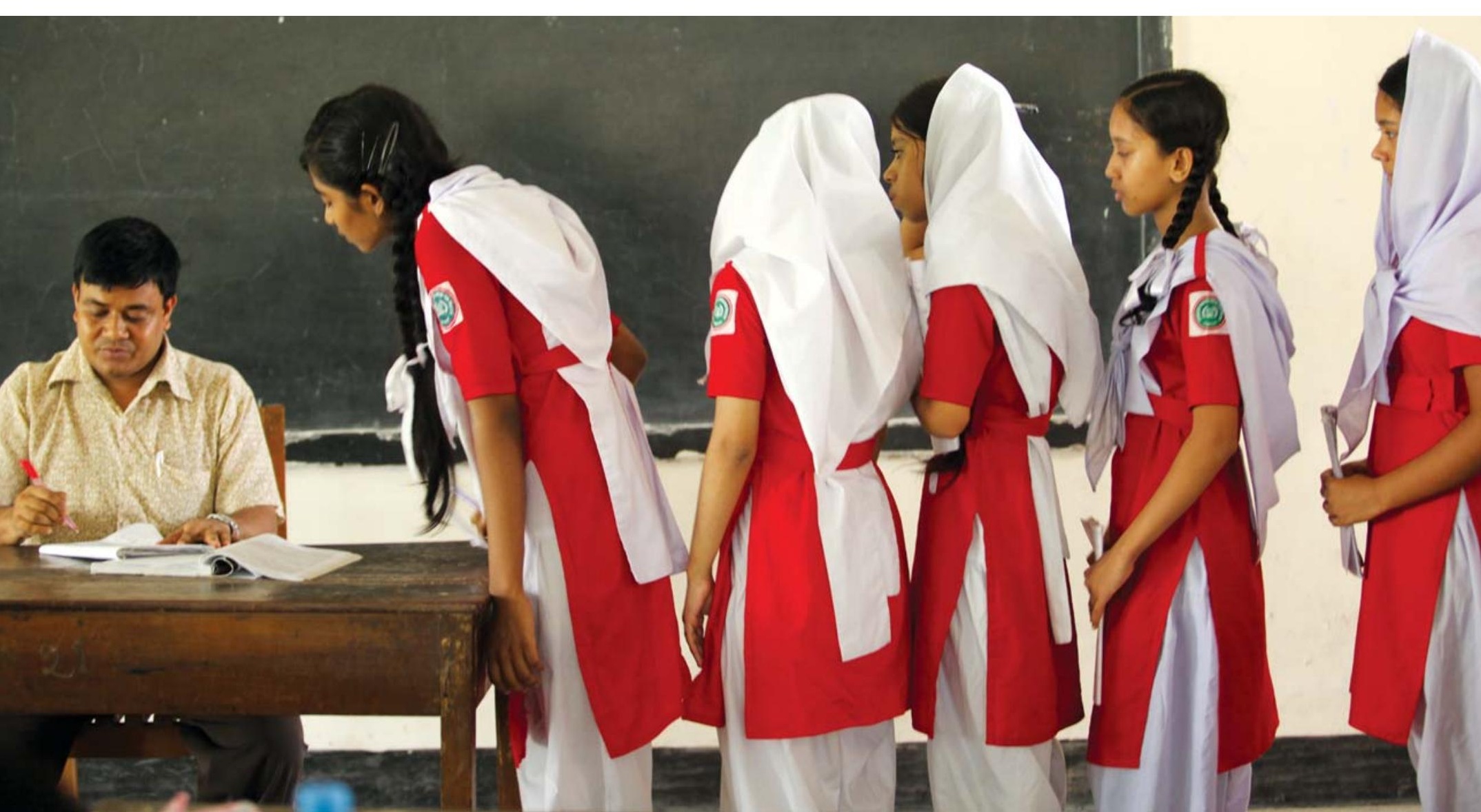

The program

became a

model of

harmonized

agency

procedures for

funding,

financial

management,

procurement,

reporting,

monitoring,

auditing, and

evaluation.

Extensive reforms in curricula, teaching methodology and management are helping students to learn better at school 


\section{Livable Cities and Towns}

\section{A wide-ranging project to strengthen urban governance and infrastructure demonstrates how to engage the poor to improve their living conditions under rapid urbanization.}

Shyamoli Sutradhar used to live in a slum. Once a place of misery, her home is now a clean new housing complex for 450 families with piped water, electricity, proper sanitation, and paved roads. The old slum had no such amenities, said the 32-year-old wife and mother of three.

Sutradhar's pourashava (municipality) of Moulvibazar was transformed with the support of the Urban Governance and Infrastructure Improvement (Sector) Project (UGIIP). ADB designed the project with three goals: improve financial accountability and management in cities, strengthen community participation, and overhaul basic infrastructure. Working together, pourashava representatives and ADB solved several core problems by improving governance, tax collection, gender equity, and service quality.

The urban population of Bangladesh has grown by $6 \%$ annually for more than 4 decades and is expected to double by 2035. To expand on the success of the original project, which began in 2002, ADB approved in 2008 the Second Urban Governance and Infrastructure Improvement (Sector) Project for $\$ 87$ million, with cofinancing from German development cooperation through GIZ and $\mathrm{KfW}$. The second phase covered 47 pourashavas, up from 30 in the first.

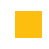

Working

together,

pourashava

representatives

and ADB

solved several

core problems

by improving

governance, tax

collection,

gender equity,

and service

quality.

Urban transportation improvement is a key to sustainable urban development

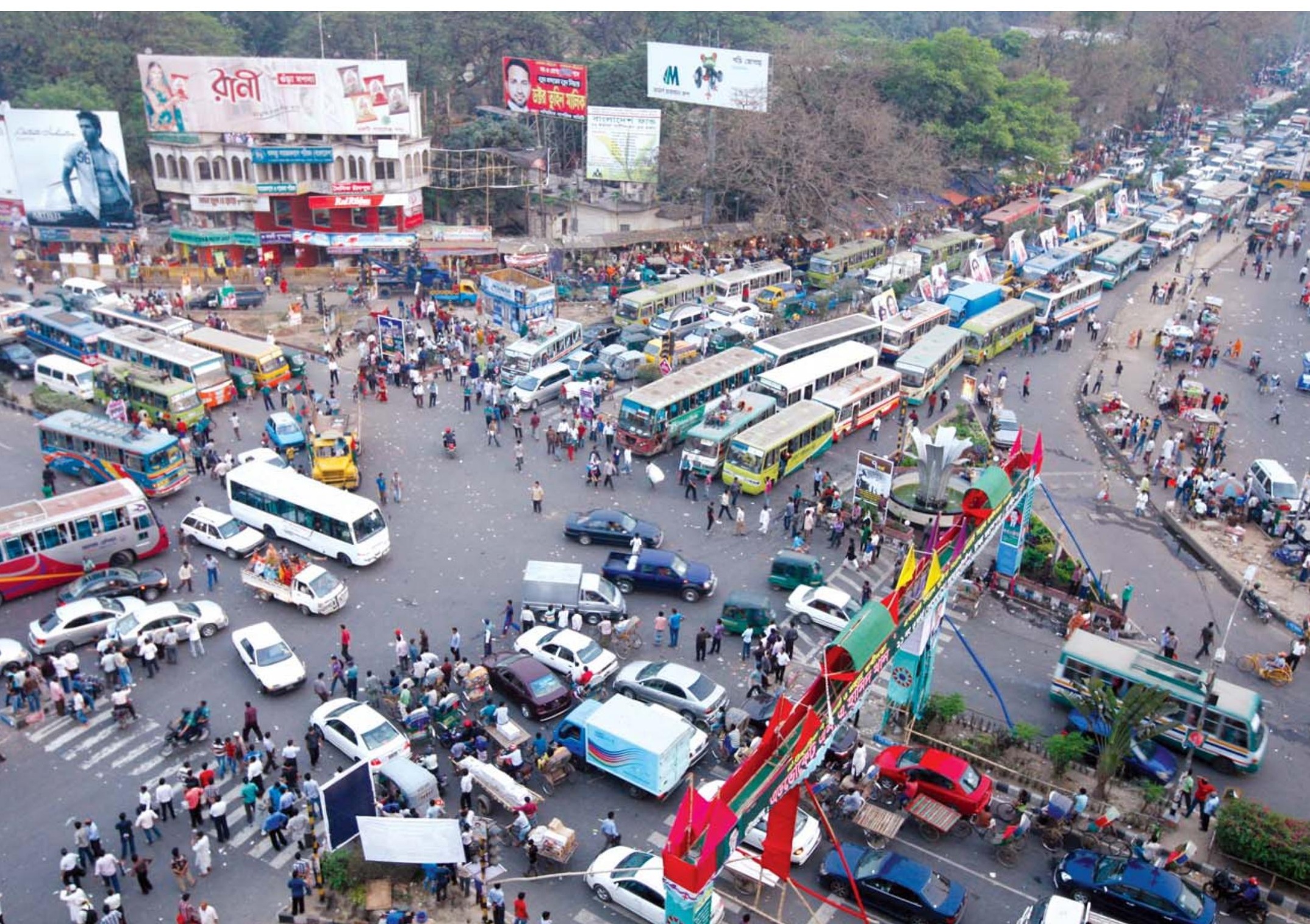


A 'courtyard meeting' under UGIIP-2: decisions made through consultative process hold better implementation potentials
The second phase laid $30 \mathrm{~km}$ of electric transmission and distribution lines and installed 461 electric posts and 5,353 street lights. It constructed footpaths, bridges, and culverts; some 186 tube wells and associated water supply pipelines; public and private toilets with $131 \mathrm{~km}$ of drains; dustbins; solid waste disposal grounds; kitchen markets and slaughter sheds; community centers; bus and truck terminals; parking areas; municipal parks; and boat landings.

Further, it built and rehabilitated $1,084 \mathrm{~km}$ of roads, encouraging growth in motorized traffic and vastly improving prospects for many local businesses. When, for example, the first phase widened and paved a road in central Moulvibazar, Abdus Shahid Tarafdar, a dealer in motor parts and accessories, saw his daily turnover more than double from $\$ 84$ per day to \$192. "Now I can bring in truckloads of goods right to my doorstep," he said.

Pourashavas used project funds to improve health and education services in poor areas. The pourashava of Bhairab now runs 25 elementary schools that provide free education to 15,000 children, including members of disadvantaged castes, and another 166 satellite schools. Working with nongovernment organizations, the project helped train 500 workers to deliver better primary health care in the community.

Kanti Lal Vasfor, whose Harijan social caste was for centuries allowed to work only as cleaners, moved into a new project-financed housing complex in Moulvibazar with 31 other Harijan families. "We lived with no permanent roof overhead and only makeshift toilets," he recalled. "We were often

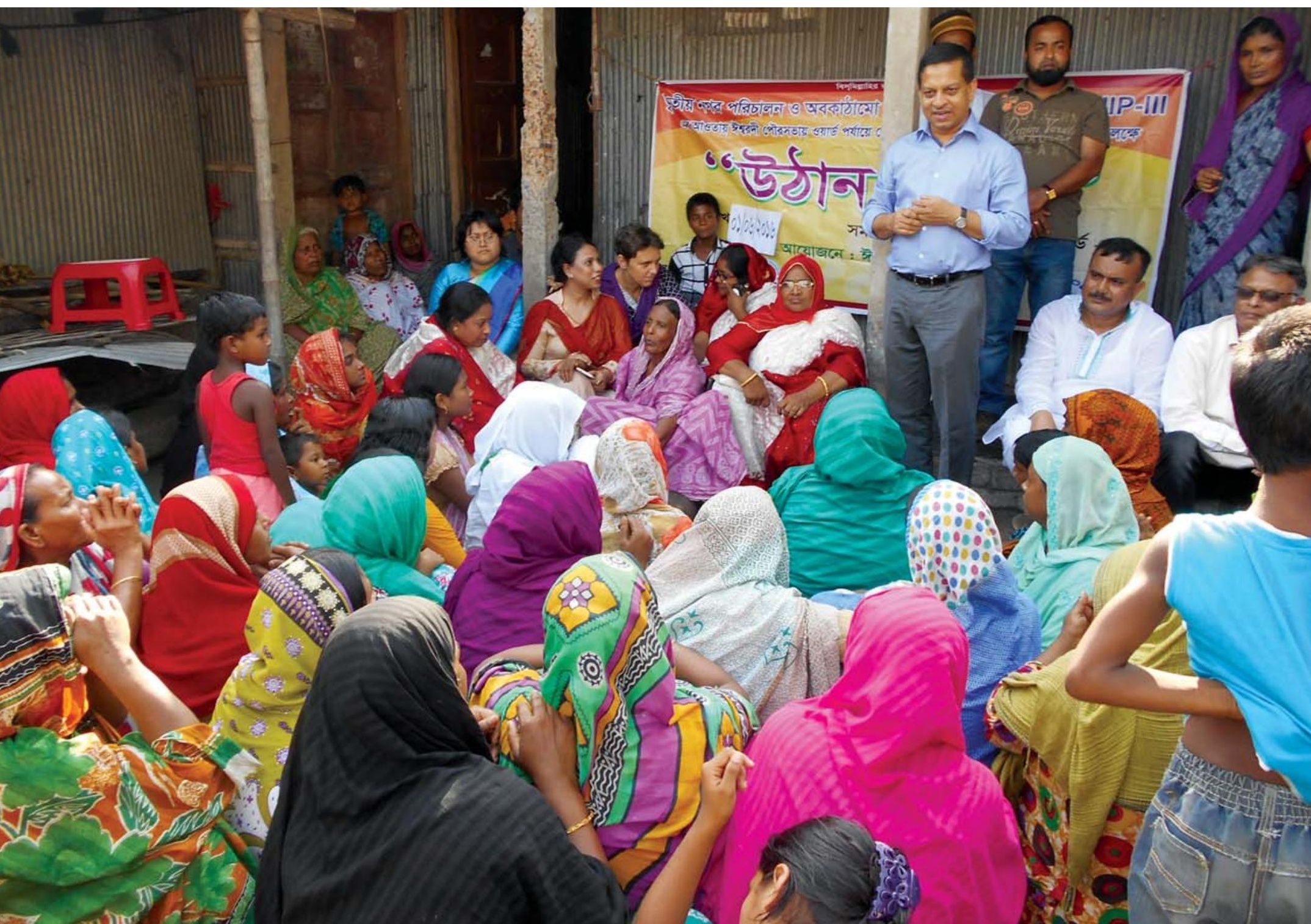


reduced to drinking water from a nearby pond. Our children suffered all kinds of diseases and rarely received any education."

His community now receives regular monthly visits from the pourashava medical officer, and the children go to local schools. Such results prompted some members in the Harijan community to volunteer to help expand project coverage. Chanchala Vasfor, for example, conducts free preschool classes in her housing complex for 2 hours every day.

"Almost all the children of nursery and preprimary age come, thanks to parents' increased awareness of the need for education," she reported.

The project's gender action plan sought to integrate gender considerations into development activities, both central and local, by appointing women to lead many of the newly created slumimprovement committees.

"Women councilors now often take the lead in resolving social conflict such as marital strife, family problems, and divorce through social arbitration," said Salina Hayat Ivy, the mayor of Narayanganj. The project helped her solve these problems and sustain harmony in her community.

"We're no longer just onlookers in pourashava affairs," said Tahmina Akhtar, a mother of four and enthusiastic member of Moulvibazar's town-level coordination committee, adding that officials now listen to their views and incorporate their suggestions. "We play a prominent role in the annual budget."

Some project microfinance initiatives provided credit specifically for women. Mala Rani Das joined a 15 -member credit group for women in Bhairab that allowed her to borrow $\$ 240$, which she used to expand her broom-making enterprise. She now earns $\$ 72$ per month, which is higher than the average wage for factory workers in Bangladesh. Each borrower is required to deposit $\$ 0.36$ per month in a savings account at a state-run bank for use in emergencies, as many poor families live only one crisis away from destitution and hunger.

Project success depended in part on the requirement that candidate pourashavas meet performance criteria such as empowering women or be dropped from the project. Further, fund allocation was conditional on pourashavas' execution of governance reform, which included the establishment of coordination committees for towns and wards. These committees boosted the participation of women and the poor in decision making, prompting the government to formalize them under the Local Government (Pourashava) Act, 2009.

Involving a community in operating and maintaining facilities and delivering services helps ensure that all residents benefit from urban infrastructure projects. The poor and disadvantaged in particular gained new opportunities to express their opinions, learn of their responsibilities as citizens, and understand local governments' duty to deliver. Each pourashava prepared a citizens' charter for public display that detailed the services it was required to provide, facility locations, and fees.

The success of the second project, completed in 2015, prompted the approval of a third phase cofinanced by the OPEC Fund for International Development. ADB has extended the project's performance-based approach to other projects, and the World Bank and the Japan International Cooperation Agency have adopted similar performance links in their own municipal projects. 
The project raised farmer

incomes by $21 \%-56 \%$, depending on the crop mix.

Due to successful initiatives, small farmers have improved their income and nutritional status

\section{Harvesting Potential}

\section{A project in rural Bangladesh trained and informed farmers to help them improve their crop mix and quality toward maximizing returns.}

Tens of thousands of smallholder farmers and their families in northwestern Bangladesh have improved their livelihoods by growing spinach, mangoes, ginger, and a vast array of other vegetables, fruits, and spices.

Rice has been the traditional smallholder crop in one of the country's poorest regions for as long as anyone can remember. Then the Northwest Crop Diversification Project, supported by ADB and implemented by the government in partnership with nongovernment organizations (NGOs), helped many households switch to more lucrative crops by providing production know-how, extension services, and credit.

Initiated in 2000 and completed in 2010 , the project raised farmer incomes by $21 \%-56 \%$, depending on the crop mix, by helping them add 43,000 hectares of high-value crops, upgrading 77 rural markets, and providing $\$ 14$ million of credit to 110,000 farmers in over 10,000 beneficiary groups organized under the project.

The $\$ 46.3$ million project helped Bangladesh accelerate economic growth in the northwest through the production of improved high-yield varieties of vegetables, fruits, spices, and other high-value

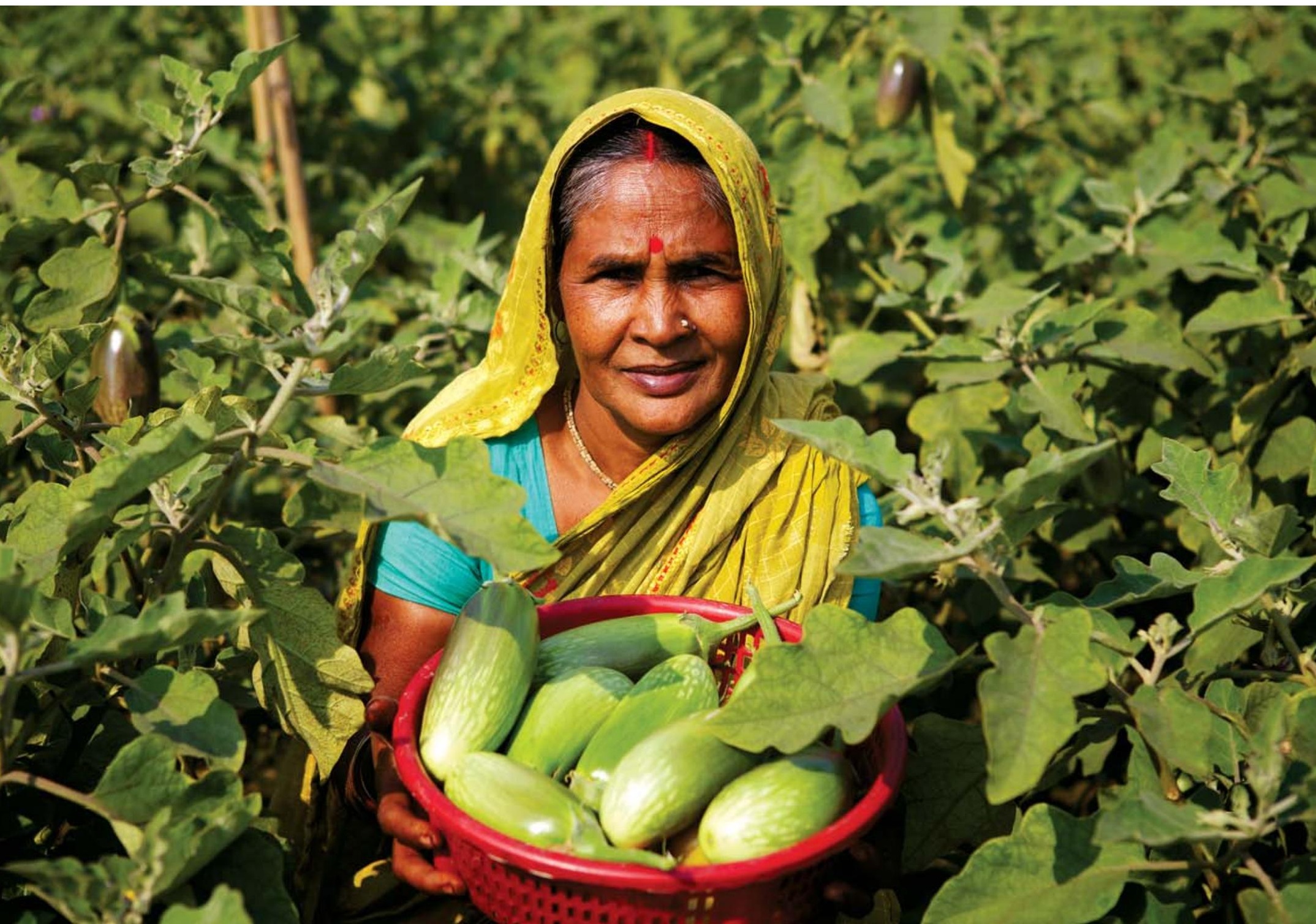


crops by farmers who now enjoy production credit and marketing assistance. The regional economy grew with crop diversification toward market-oriented crops.

Before the project, smallholders typically eked out a marginal living by growing rice on plots averaging 1.2 hectares, as well as some livestock. They adhered to this tradition because they lacked the knowledge and opportunity to produce and market higher-value crops that could boost their incomes. They were hamstrung as well by a lack of credit, as banks required collateral and NGOs focused on the most marginal farmers and landless agricultural workers.

The project stepped in to respond to these needs. Along with start-up microcredit, 180,000 farmers received training, crop research data, and up-to-date price information. In addition, the project improved market-access roads and provided covered areas for produce loading, storage, and sales. It further established marketing groups to organize the sale and transport of goods both locally and in Dhaka and other major cities.

A quarter of a million smallholders, half of them women, now produce crops that can earn them much more than even high-yielding varieties of winter rice.

Hazera Begum, a member of the marketing group in the village of Niyamatpur, earns from her new enterprise about Tk3,000 per month, or $\$ 43$, which is double the amount that her husband brings home as a rickshaw driver.

Food processing industries have high potentials for value addition

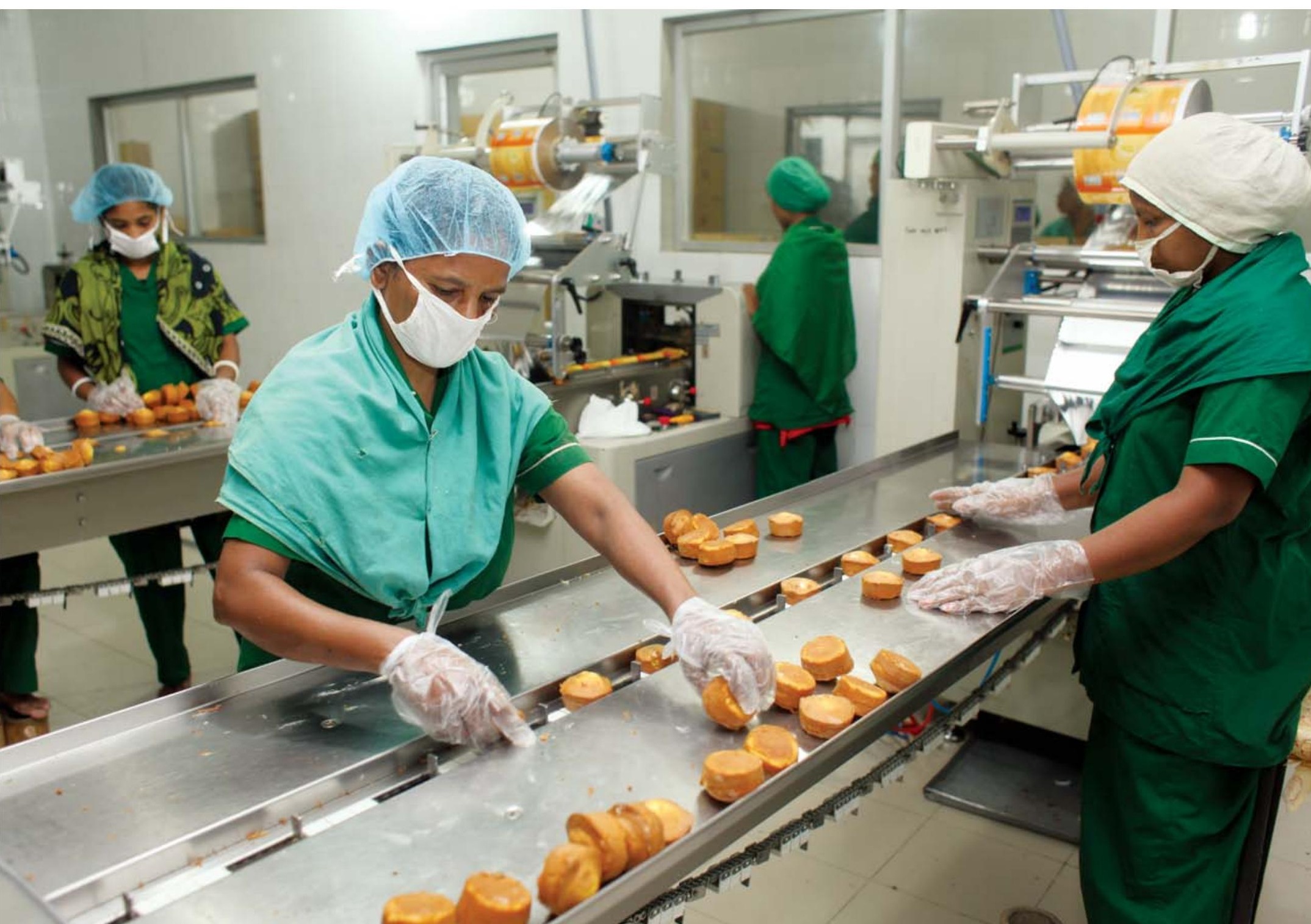


Noteworthy

NGOs involved

in the project

included the

BRAC,

Grameen

Krishi

Foundation,

PROSHIKA, and RDRS.
"I've already paid back initial loans of Tk30,000 that I used to produce eggplants, spinach, country beans, and other vegetables," said the 25 -year-old mother of three. "We have a far better life now with the additional income. We are very happy as our children can go to school, and we have renovated our home. I'm looking for an available plot to produce leeks, tomatoes, and other highvalue vegetables."

Such success was facilitated by strong project monitoring, demonstration trials in farmers' fields, the provision of advice onsite from the Department of Agricultural Extension and NGO fieldworkers, and ample credit support. Market demand and the keen interest of beneficiary farmers were also key to success. ADB contributed $70 \%$ of the $\$ 66$ million project price tag, with the government and project beneficiaries as a group each providing about half of the remainder.

Among the 33 high-value crops identified for project support were potato, maize, cabbage, tomato, country bean, spinach, okra, pumpkin, cucumber, mango, tamarind, ginger, and onion. Noteworthy NGOs involved in the project included the Bangladesh Rural Advancement Committee (BRAC), Grameen Krishi Foundation, PROSHIKA, and Rangpur Dinajpur Rural Service (RDS) Bangladesh. NGOs were estimated to have provided $\$ 25$ million in credit to farm households by the end of 2009 .

Half of the 3.2 million farm families in the project area lived below the national poverty line. Their plight was exacerbated in the past by physical isolation from markets on the far side of the Jamuna River to the east and the Padma River to the south. With the opening of the Bangabandhu Bridge in 1998 as a link between the northwest and the rest of Bangladesh, a broad range of new economic opportunities arose (A Bridge to Prosperity, page 15).

The Northwest Crop Diversification Project took advantage of improved accessibility, especially as an ADB study had identified agricultural development as an important way that northwestern Bangladesh could spur economic growth and reduce poverty.

It also ensured that women became fully included in income generation. More than $10 \%$ of households in the project area were headed by women, and a major focus was placed on ensuring they had access to training, information, and credit programs. In Gochirampur, where nearly all of the project beneficiaries were women, weekly meetings were held to discuss issues of concern and share solutions.

"These weekly meetings give us opportunities to talk about our children's education, health, irrigation, and other matters, and we try to help each other solve problems," said 40-year-old Zaheda Islam. "With advice from other women, I've been able to improve my business and for the first time engage my husband in discussions about important family matters." 


\section{Power to the People}

\section{Significantly improved generating capacity and reliability serves growing demand for electricity from an expanding economy and grateful consumers.}

Ashraf Chowdhury owns a large factory at Kachpur in Dhaka that produces ready-made garments for export. Today, his factory enjoys fairly reliable electric power supply, with only occasional cuts even at times of peak usage. It was not always so.

"I shudder recalling the turbulent days in the 1990s, when electricity supply was at its poorest," said the 55 -year-old entrepreneur. "We endured about 6 or 7 hours of load shedding on average every day."

Chowdhury owes thanks to a generating plant that came online in 2002 some $20 \mathrm{~km}$ to the southeast of Dhaka at Meghnaghat, a 25 hectare site on the north bank of the Meghna River. The 450 megawatt combined-cycle power plant, fired exclusively by indigenous gas, recorded an annual availability rate

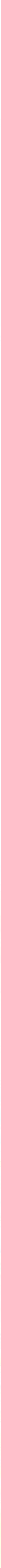


of $91.9 \%$ from 2002 to 2010 , at the end of which it provided $11 \%$ of average generation capacity in Bangladesh. It produces an average of 3,154 gigawatt-hours of power every year.

The plant features full effluent treatment, fire control systems, waste management facilities, and other systems required to maintain and monitor daily operations. It is controlled through modern computers and software. All control functions that affect the availability of the generating units are duplicated and available at several control levels to ensure adequate backup.

Meghnaghat power plant is the first public-private partnership in the power sector in Bangladesh.

ADB supported in improving power transmission and distribution networks
The Meghnaghat power plant is the first public-private partnership in the power sector in Bangladesh. Assisted by ADB private sector operations, the Meghnaghat Power Project built the plant through a build-own-operate structure that saw the Meghnaghat Power Company formed to perform these functions. ADB supported the project with a \$50 million loan, a \$20 million complementary financing loan, and a political risk guarantee of $\$ 70$ million. A consortium of commercial banks and other financial institutions provided an additional $\$ 80$ million.

The project has changed lives. Before the plant was operational, annual electricity consumption per capita in Bangladesh was just 70 kilowatt-hours, one of the lowest in the world. By 2010 , with the aid of the Meghnaghat plant's contribution to the national grid, this figure had more than tripled to 220 kilowatt-hours.

"My children could not study in the evening because power cuts were frequent during the peak hours from 6 p.m. to 9 p.m.", recalled Parveen Sultana, a middle-class housewife in the Rampura area in Dhaka. "When power was restored at around 10 p.m., my children were already sleepy. They are older now and routinely study after sunset till 10 p.m. with fluorescent lights overhead. Power cuts are now less frequent and shorter. I don't have to keep stock of candles these days."

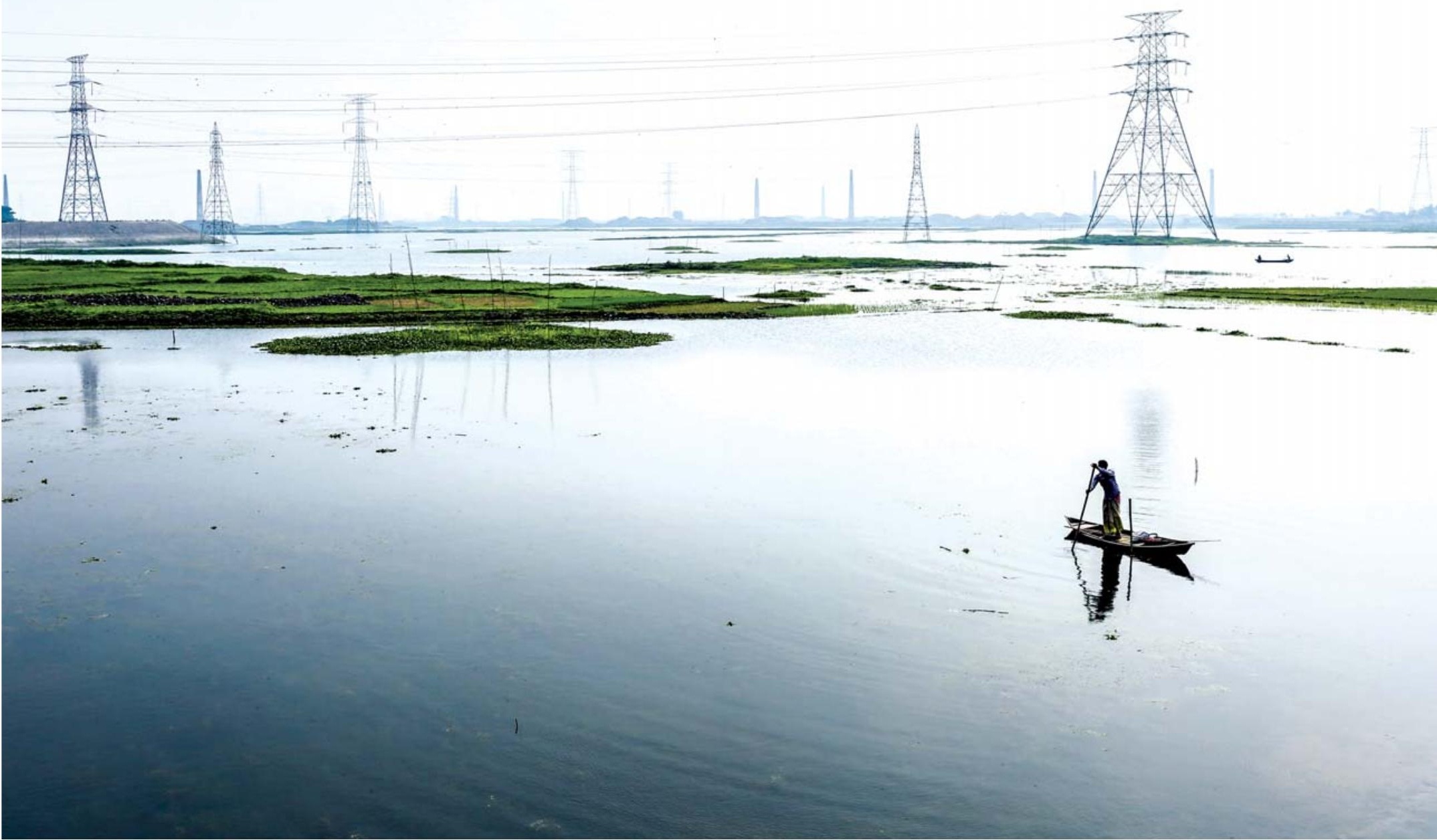


Improved service was the result of higher supply thanks in part to the Meghnaghat power plant combined with improved distribution. Improving electric power services did not come easily. Service was poor in the 1980s. The situation was so dire that development partners suspended assistance. ADB then initiated a meeting in December 1992 with the government and other development partners that produced an agreement among development partners to extend external assistance for projects that entailed reform. A significant milestone was passed when the government adopted a policy paper in 1994 that formed the basis for sector reform.

The Rural Electrification Project, approved the following year, was the first ADB-financed project in the Bangladesh power sector with a reform link. The second was the more comprehensive Ninth Power Project, approved in 1996. Among the main objectives of this project was to efficiently evacuate and use the electricity to be generated by the Meghnaghat Power Company.

Another main objective was to initiate the vertical unbundling of the Bangladesh Power Development Board into generation, transmission, and distribution entities. The success of the Meghnaghat Power Company demonstrated how effectively the private sector could build and operate power infrastructure under a regime with strong corporate governance, transparency, and professional work ethics.

Over $60 \%$ of the electric power now produced in Bangladesh comes from the private sector, the Meghnaghat Power Project having laid the foundation for this achievement. Competitive electricity generation by independent private operators is now an accepted feature of the power market, and new power sector institutions are achieving good results.

A gas insulated switchgear substation

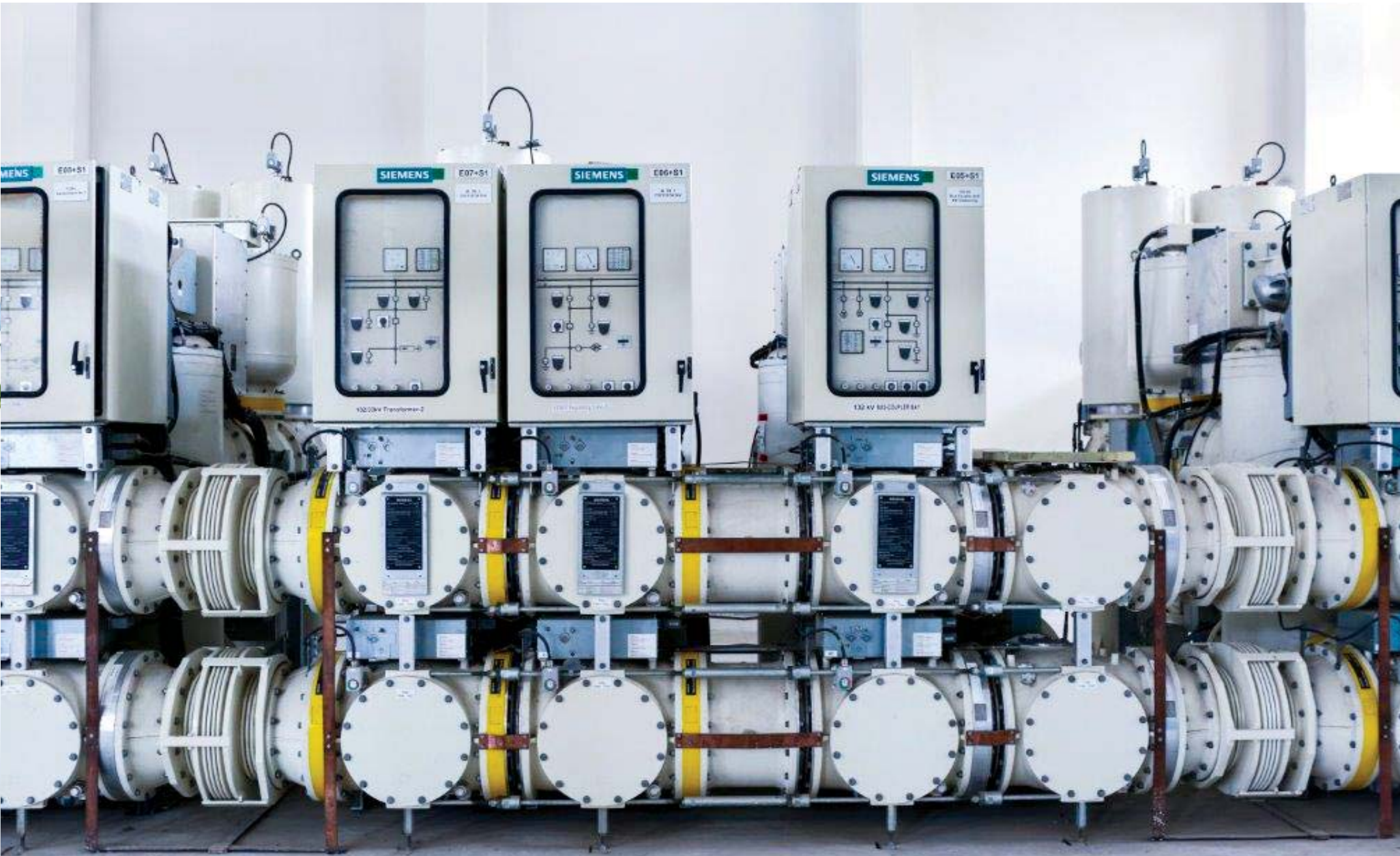




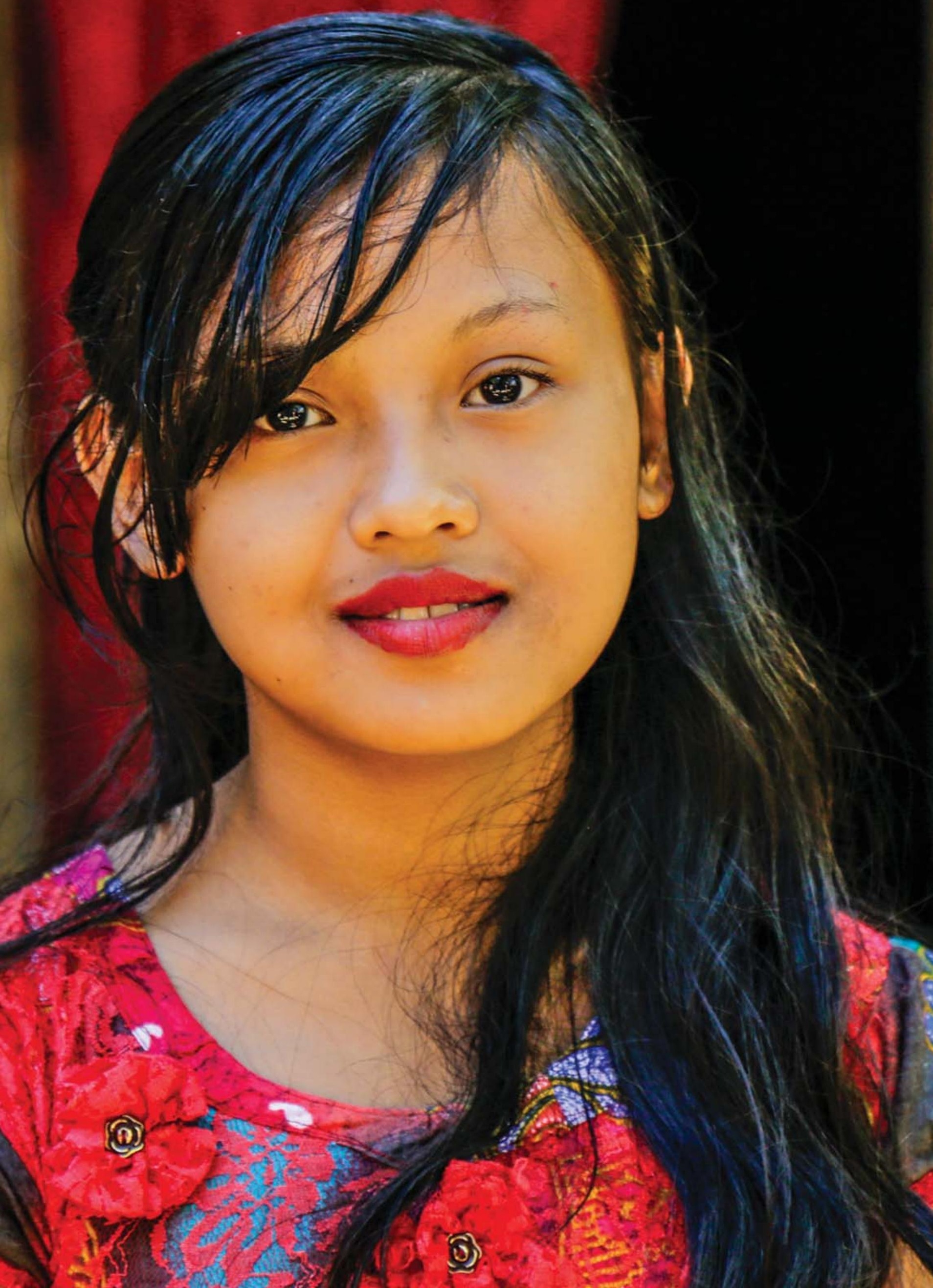




\section{MAKING RESULTS VISIBLE}

The Bangladesh-ADB development partnership has yielded measurable improvements in sectors including transport; energy infrastructure; education; agriculture and natural resources; urban development; and finance. Ongoing and planned projects promise further results.

Following are some development contributions from ADB-assisted projects in Bangladesh.

- The Secondary Education Development Project, initiated in 1993, benefited 7.3 million children as secondary school enrollment increased from $34.9 \%$ in 1996 to $41.3 \%$ in 1999.

- The Urban Primary Health Care Project, a public-private partnership initiated in 1997, benefited over 6 million people through 180 urban health care centers.

A worker at a garments factory: $A D B$ prioritizes development of skills relevant to market needs

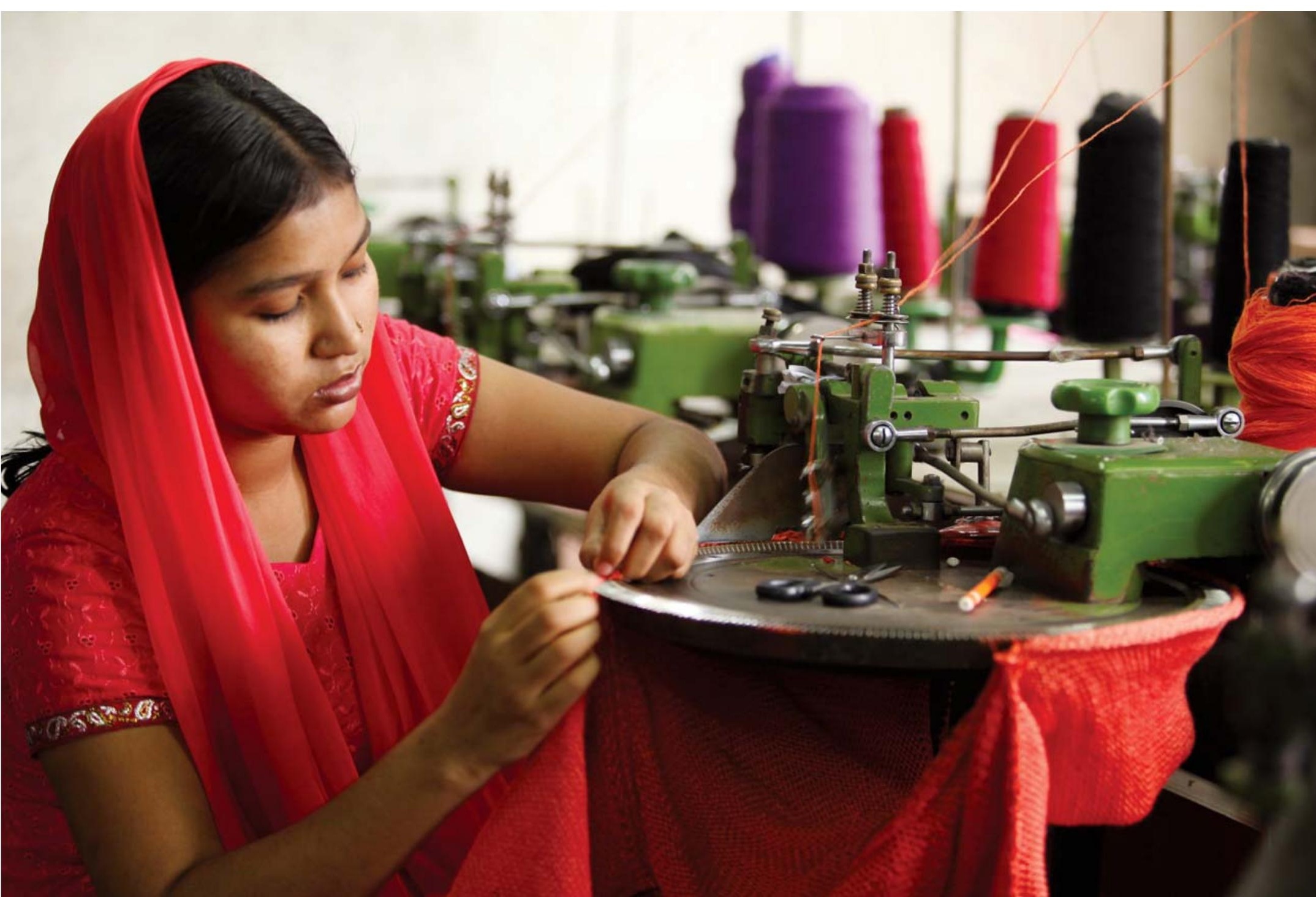


- The Southwest Road Development Project, approved in 1999, reduced vehicle operating costs in the corridor by $38 \%$ and helped the regional gross domestic product grow by $6 \%$ annually in 1999-2005, or half a percentage point higher than the national average.

- The Emergency Flood Damage Rehabilitation Project, approved in 2005, financed the rehabilitation of $5,500 \mathrm{~km}$ of rural roads.

- The Chittagong Port Trade Facilitation Project, completed in 2013, introduced an automated management system and helped develop a strategic master plan for the next 30 years.

- The Second Rural Infrastruture Improvement Project, completed in 2013, built or upgraded $1,425 \mathrm{~km}$ of rural roads.

- The ongoing Railway Sector Investment Program implemented system reform and financed 64 $\mathrm{km}$ of double-tracking along the railway corridor from Dhaka to Chittagong port, shortening travel time by 1 hour for passenger trains and by $5-6$ hours for freight.

- The Sustainable Power Sector Development Program, completed in 2014, installed 300 megawatts of new generating capacity, and constructed 1,610 km transmission and distribution lines and connected 461,000 households.

Solar panels:

Cleaner energy development holds

the key to

sustainable

development
- The Gas Transmission and Development Project, approved in 2005, constructed $270 \mathrm{~km}$ of distribution lines, $353 \mathrm{~km}$ of transmission lines, and 4 compressor stations.

- The Natural Gas Access Improvement Project, approved in 2010, constructed $61 \mathrm{~km}$ of transmission lines and installed 4 compressor stations and 8,600 prepaid meters.

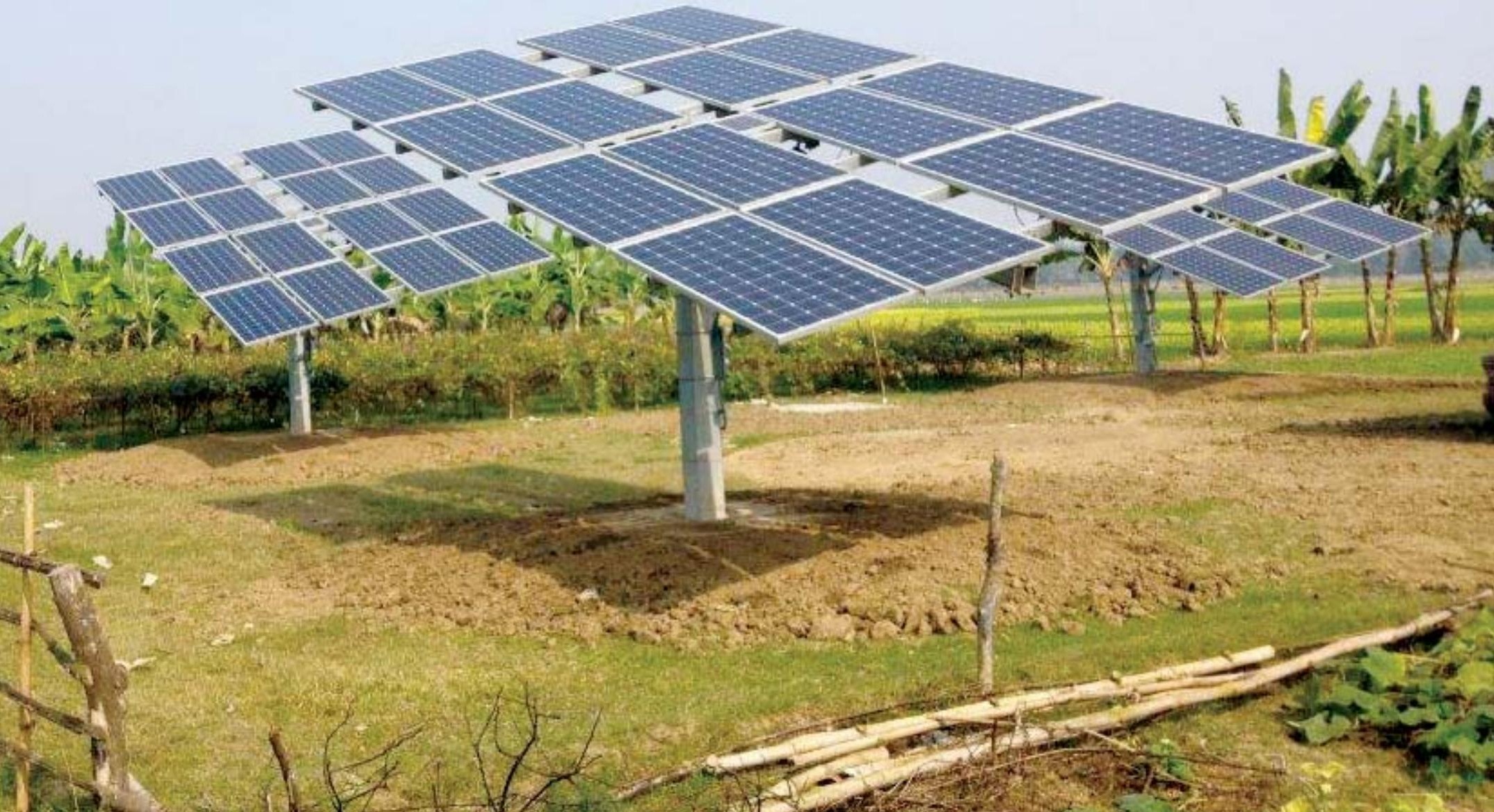


- The Secondary Education Sector Development Project, completed in June 2014, helped construct 63 new schools, update curricula, and develop criteria for distributing stipends to poor students in 53 underserved subdistricts.

- The Skills for Employment Investment Program, approved in 2014, has trained almost 55,000 (including 14,000 women), 31,500 of whom (including 11,000 women) have since found jobs.

- The Southwest Area Integrated Water Resources Planning and Management Project, completed in 2015 , benefited over 80,000 farm households by intensifying annual cropping by 20 percentage points to $210 \%$.

- The Secondary Towns Water Supply and Sanitation Project, completed in 2016, helped improve living conditions and health standards in secondary towns, connecting $73 \%$ of households in project areas and significantly curtailing diarrhea and dysentery.

- The Dhaka Water Supply Sector Development Program, completed in 2016, benefited some 100,000 poor and disadvantaged people in Dhaka by providing access to safe and clean water and encouraged the Dhaka Water Supply and Sewerage Authority to replicate the pilot in other slums.

- The Second Public-Private Infrastructure Development Facility, approved in 2013, has so far financed 46,760 home solar systems.

- The Second Capital Market Development Program, approved in 2012, enhanced the operational and financial efficiency of the Bangladesh Securities and Exchange Commission and helped to modify the governance structure of the Dhaka and Chittagong stock exchanges to separate ownership from management.

- The PRAN Agribusiness Project, approved in 2012 as the first ADB-supported nonsovereign agribusiness project in 27 years, helped the PRAN corporation buy in 2014-2015 some 40,000 tons of cassava directly from farmers for use in newly built food-processing plants.

- Through a \$430 million multitranche financing facility for the Bangladesh Railway Sector Investment Program, completed in 2016, ADB helped Bangladesh Railway upgrade rolling stock and construct $64 \mathrm{~km}$ of new railway line. Features include a new signaling system from Tongi to Bhairab Bazar railway junction along the Dhaka-Chittagong Railway Corridor, which connects Chittagong port as well. The program introduced commercial accounting, created lines of business with measurable goals, and corporatized the container business.

- Under the South Asia Subregional Economic Cooperation Program (SASEC), the Second SASEC Bangladesh-India Electrical Grid Interconnection Project will help double electricity imports from India from the current 500 megawatts. The project builds on an ADB-assisted grid interconnection project that, since October 2013, has brought 500 megawatts of electricity, or about 3,000 gigawatt hours per year, across the border from India.

- The \$505 million SASEC Railway Connectivity, Akhaura Laksam Double-Track Project, approved in 2014, is being implemented to help railways better meet passenger and freight demand and promote domestic and subregional trade. Besides broad improvements to the railway system, expected project results include reduced transport costs, improved logistics in strategic corridors, and more inclusive railway services to better serve the elderly, the disabled, women, and children.

- The SASEC Road Connectivity Project is upgrading a $70 \mathrm{~km}$ stretch along a corridor connecting the northwest to Dhaka. The project will improve connectivity and support trade, both domestic and subregional.

- The SASEC Trade Facilitation Program aims to reduce nontariff barriers through the adoption of international customs administration protocols, upgrade of existing customs management systems, and establishment of a web-based electronic trade portal. 
- Under the ongoing Participatory Small-Scale Water Resources Sector Project, community infrastructure is being developed with the participation of stakeholders including farmers, fishers, landless people, and women. The project and two forerunners helped raise cropping intensity from $176 \%$ to $237 \%$, saved one crop from regular flooding, added 390,000 tons of additional harvests, and annually created 6.27 million person-days of employment.

- The $\$ 440$ million Third Primary Education Development Project approved in 2011, aims to improve education quality, gender parity, and retention. In 2016, water was supplied to 10,000 schools, new toilet blocks were built in 5,000 schools, and 19.7 million primary students received free textbooks at the start of the school year.

- The \$55 million Second Chittagong Hill Tracts Rural Development Project approved in 2011 and implemented in Bandarban, Khagrachari, and Rangamati hill districts, had by June 2016 built $53.2 \mathrm{~km}$ of feeder roads and 6 market buildings, allocating $50 \%$ of the building space to women. The project created 4,648 days of work for people, including 2,395 for women, thus enabling women to be more directly engaged earning livelihoods in suitably constructed marketplaces. Rural road subprojects in the three districts are in various stages of implementation. Community infrastructure has been completed in 185 villages.

- The $\$ 700$ million first tranche of the Power System Efficiency Improvement Project and the Power System Expansion and Efficiency Improvement Investment Program are adding 251

An undermegawatts to the national grid by upgrading old power plants into combined-cycle systems.

construction power plant: infrastructure development remains a key priority of $\mathrm{ADB}$ in Bangladesh Such modern plants generate $60 \%$ more electricity with the same energy inputs, thereby enhancing environmental sustainability.

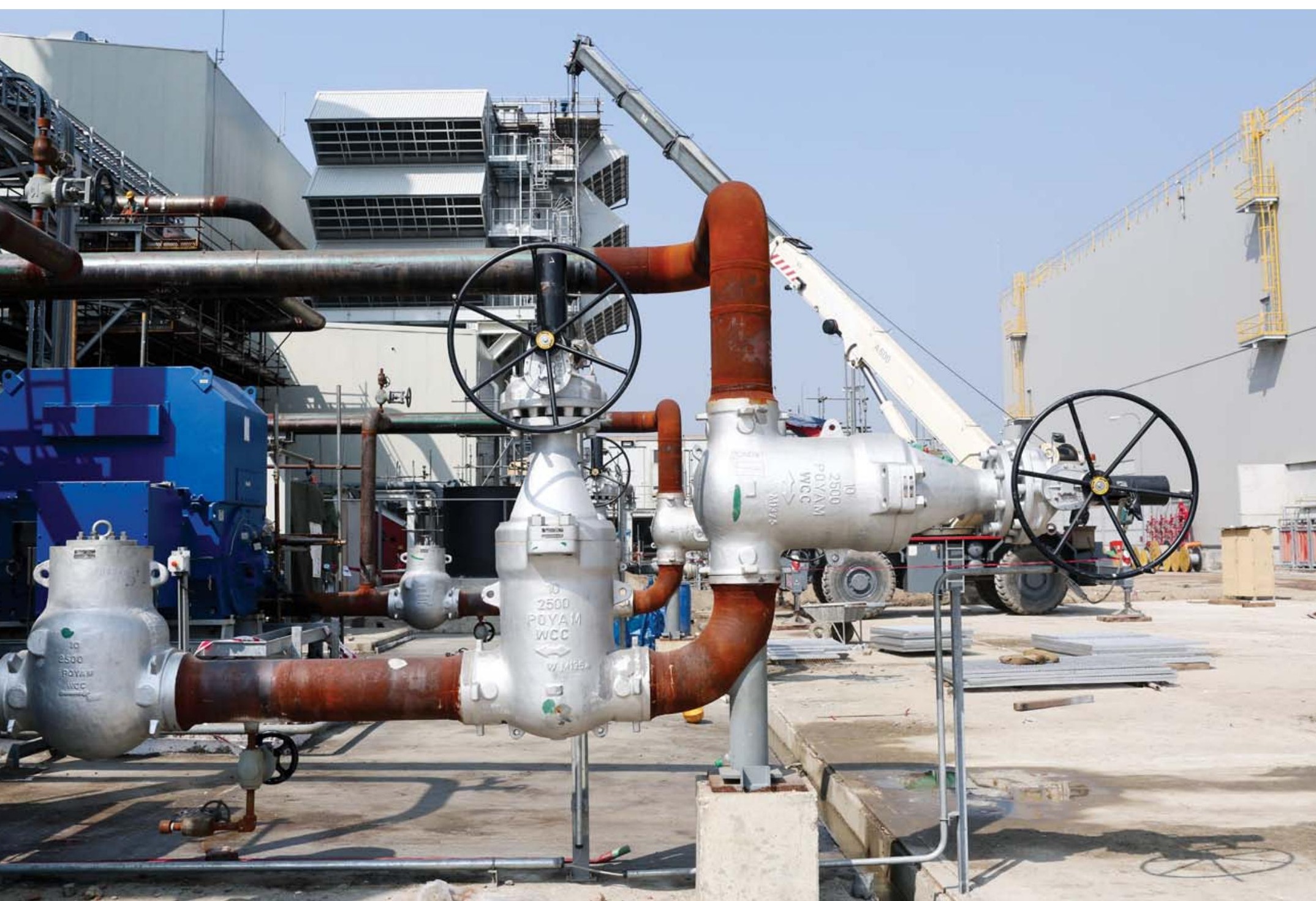




\section{LOOKING AHEAD}

ADB aims to scale up lending to Bangladesh to $\$ 8$ billion during 2016-2020, the period corresponding to the new country partnership strategy. This is a significant increase from $\$ 5$ billion during 2011-2015. Projects to be implemented in this period will enhance infrastructure and human capital toward diversifying the economy; boost climate and disaster resilience; develop economic corridor; improve rural livelihoods; and strengthen regional trade links, especially for energy.

Toward developing energy infrastructure, support will be provided to enhance electric power and gas generation, transmission, and distribution. Support will also be extended to developing renewables and regional power sharing facilities. In transport, support will focus on developing railways and roads, including for regional connectivity.

Bangladesh cut infant and maternal mortality by more than two-thirds during 1990-2015

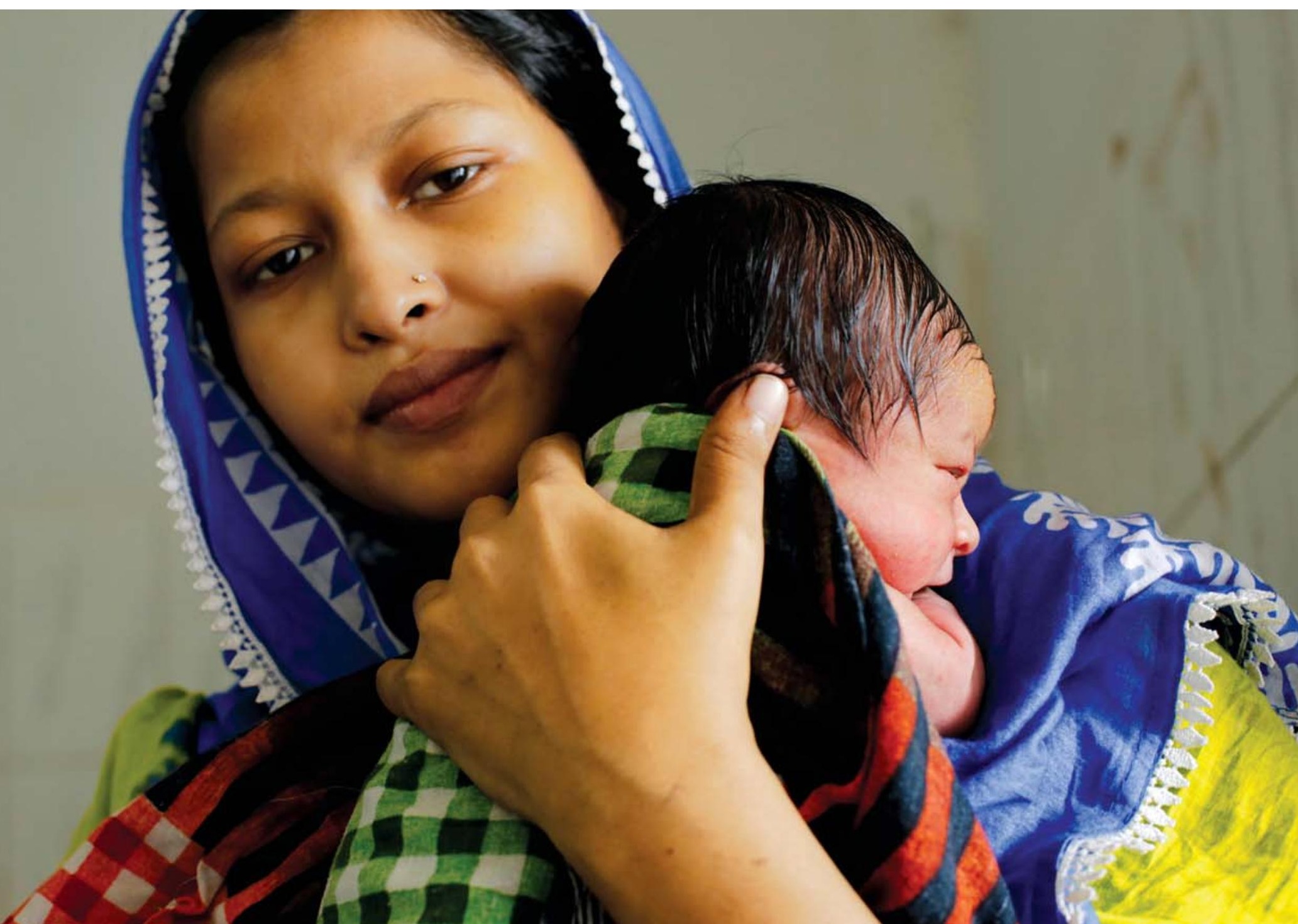


ADB will focus on human capital development through training the country's large young workforce.

To help Bangladesh meet its employment challenge, ADB will focus on human capital development through training the country's large young workforce, imparting quality education, and developing skills relevant to market needs.

As Bangladesh is urbanizing rapidly, ADB will intensify support for developing urban infrastructure and services to improve urban living conditions and help people take advantage of the higher economic productivity of urban centers. ADB will continue to support improved municipal infrastructure and services in secondary towns, including coastal areas vulnerable to climate change and natural disasters, while paying attention to improving local government performance.

ADB will seek to boost rural productivity and income, and make villages more livable, to alleviate pressure to migrate to cities. It will support balanced rural and regional development by building rural infrastructure, facilitating agribusiness, and developing growth centers along economic corridors.

Bangladesh is set to progress toward achieving the Sustainable 
Improving Lives Together in Bangladesh

50 Years of the Asian Development Bank

Since Bangladesh's partnership with the Asian Development Bank (ADB) in 1973, the country has seen significant socioeconomic gains with a steady rise in gross domestic product, boost in social development, and meeting the Millennium Development Goal of halving the incidence of poverty from $57 \%$ in 1990 to less than $24 \%$ in 2016. As of December 2016, ADB's cumulative assistance for Bangladesh amounted to $\$ 18.3$ billion for 265 loans, and $\$ 249.5$ million for 419 technical assistance projects. ADB aims to increase lending to Bangladesh to $\$ 8$ billion during 2016-2020, a significant increase from $\$ 5$ billion during 2011-2015.

\section{About the Asian Development Bank}

ADB's vision is an Asia and Pacific region free of poverty. Its mission is to help its developing member countries reduce poverty and improve the quality of life of their people. Despite the region's many successes, it remains home to a large share of the world's poor. ADB is committed to reducing poverty through inclusive economic growth, environmentally sustainable growth, and regional integration.

Based in Manila, ADB is owned by 67 members, including 48 from the region. Its main instruments for helping its developing member countries are policy dialogue, loans, equity investments, guarantees, grants, and technical assistance. 